\title{
Geospatial and Geostatistical Analyses of Particulate Matter (PM10) Concentrations in Imo State, Nigeria
}

\author{
Opara Alex Iheanyichukwu ${ }^{1 a}$, * Ibe Francis Chizoruo ${ }^{2,3 b}$, \\ Njoku Pascal Chukwuemeka ${ }^{3 c}$, Alinnor Jude Ikechukwu ${ }^{3 \mathrm{~d}}$ \\ and Enenebeaku Conrad Kenechukwu ${ }^{3 e}$ \\ ${ }^{1}$ Department of Geology, Federal University of Technology P.M.B.1526, Owerri, Imo State Nigeria. \\ ${ }^{2}$ Department of Chemistry, Imo State University P.M.B 2000, Owerri, Imo State Nigeria. \\ ${ }^{3}$ Department of Chemistry, Federal University of Technology P.M.B. 1526, \\ Owerri, Imo State Nigeria. \\ E-mail address: aoparazanda2001@yahoo.com, *bibefrancis@imsu.edu.ng,

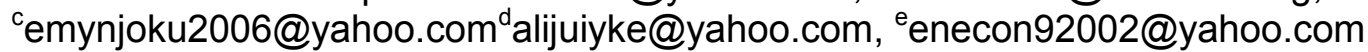

Keywords: Geospatial, variation, particulate matter $\left(\mathrm{PM}_{10}\right)$, air pollutant, environment

\begin{abstract}
Geospatial and geostatistical analysis of particulate matter $\left(\mathrm{PM}_{10}\right)$ variation in Imo State, Nigeria was carried out. The objectives of the study were to determine and analyze the variation in concentration of ambient $\mathrm{PM}_{10}$ level in Imo State, Nigeria. Air quality sampling was conducted within November 2014 and June 2015, in wet and dry seasons three times daily using Haze Dust Particulate Monitor $(10 \mu \mathrm{m})$. The mean concentration of $\mathrm{PM}_{10}$ level observed in the study varied from $5.22-6.63 \mathrm{mg} / \mathrm{m}^{3}$ in wet season and $5.80-8.38 \mathrm{mg} / \mathrm{m}^{3}$ in dry season. Coefficient of variation $(\mathrm{CV} \%)$ revealed that the variability of $\mathrm{PM}_{10}$ level ranged between little and moderate variations in both wet and dry season. Analysis of variance (ANOVA $\mathrm{p}<0.05$ ) showed statistically significant variation in the mean $\mathrm{PM}_{10}$ level in the study locations. Box and Whisker plots confirmed variation of $\mathrm{PM}_{10}$ in the morning, afternoon and evening. The GIS plots revealed the spatial attributes of the air pollutant in the study locations. Time series plots indicate that the air pollutants fluctuated throughout the study duration. The Wind Rose suggests that the prevailing wind speed and wind directions were responsible for the dispersal migration of the air pollutant in the study area. The highest seasonal mean values were observed in Egbema and Okigwe area in both dry and wet season. The seasonal mean values recorded in the study exceeded the Nigerian National Ambient Air Quality Standards. This calls for urgent response to prevent further air quality deterioration and its negative effects on man and the environment.
\end{abstract}

\section{INTRODUCTION}

Pollution of the ambient environment could be due to gaseous or particulates matter. Atmospheric pollution has been persistent as a result of continuous mixing, transformation and trans-boundary transportation of atmospheric pollutants that deteriorates the air quality of an area and makes it difficult to predict [1]. These atmospheric pollutants especially the particulate matter $\left(\mathrm{PM}_{10}\right)$ has been increasingly unabated due to population growth, urbanization, industrialization, increase in vehicular traffic and wrong implementation of strict environmental regulations, which could contribute significantly to reduction of air quality standards [2].

Particulate matter $\left(\mathrm{PM}_{10}\right)$ is one of the air pollutants emitted into the atmospheric environment by anthropogenic and natural sources which may impact negatively to air quality of the surrounding environment [3]. Pollution of the atmospheric environment due to particulate matter could be regarded as a very important air pollutant and one of the most significant sources of atmospheric pollution. This owns to the complex composition of particulate matter in the environment. Elevated levels of $\mathrm{As}, \mathrm{Pb}, \mathrm{Cd}$, and $\mathrm{Fe}$ has been reported in samples of suspended particulate matter [4]. Similarly, Chiemeka reported significant levels of $\mathrm{Ca}, \mathrm{K}, \mathrm{Mg}, \mathrm{Fe}, \mathrm{Zn}, \mathrm{Mn}$, $\mathrm{Cu}, \mathrm{Ni}, \mathrm{Cr}, \mathrm{Cd}$, and Pbin atmospheric aerosol samples [5]. In addition, Majewski et al reported presence of $\mathrm{As}, \mathrm{Cd}$ and $\mathrm{Ni}$ in samples of particulate $\left(\mathrm{PM}_{10}\right)$ matter in Warszawa, Poland [6]. 
Particulates, such as dust, soot, or smoke, are sizable or dark enough to be observed with human naked eye [7]. $\mathrm{PM}_{10}$ are atmospheric particles which could be liquid or solid, organic or inorganic particulate contaminants ranging from 0.001 to $10 \mu \mathrm{m}$ [8 - 10]. These particles are usually suspended in the atmospheric environment close to sources of air pollution like in urban atmosphere, highways, windblown dust, industrial plant vicinity, power plants, mining sites, volcanic eruption, bush burning and from agricultural practices [11 - 15].

Atmospheric pollutants such as particulate matter is one of the foremost environmental concern before developing and developed countries due to its effects on air quality standard and human health which could be acute or chronic [16,17]. Atmospheric particulates, due to their considerable environmental significance pose serious threat clean air and environmental health, the basic requirements of human existence [18, 19]. Pollution of the atmospheric environment by particulate pollutants has been linked to numerous health concerns which can worsen respiratory and cardiovascular diseases [20 -24], reduction in growth of plant and yield [25], distortion and reduction of visibility [26,27], including deformation of the esthetic and natural beauty of the environment [28].

The level of atmospheric pollution could vary due to changes with different locations and time resulting from changes in meteorological and topographical conditions. This arises due to the concentration of air pollutants depend not only on the quantities that are emitted from air pollution sources but also on the ability of the atmosphere to either absorb or disperse these emissions [29]. Variation in air pollution concentration is hinged on the space variation of sources as well as atmospheric gradients which results in diffusion and transportation to areas outside the source of the air pollution [30]. Fluctuations in time of the year or seasons have been reported to affect the observed air quality as this could influence dispersal of air pollutants by either decreasing or increasing their concentration in the atmosphere[31]. Difference in the ambient temperature, relative humidity and wind speed including wind direction could also vary the concentration of atmospheric pollutants over the seasons [32].

$\mathrm{PM}_{10}$ is one of the criteria pollutants that are regulated and monitored. It is among the air pollutants commonly employed in the determination of the air quality index /air pollution index (AQI/API) $[33,34]$. The problem of particulate matter in the atmospheric environment calls for serious concern in Nigeria especially in Imo where there are a lot of factors that could generate the particles. Majority of the roads even in the urban areas are not asphalted, this is in addition to frequent bush burning that enables the emission of this pollutant. Also, in this part of the world with two distinct seasons this atmospheric pollutant may be significant during dry season when the relative humidity is moderately low with a higher wind velocity [35 - 37]. Air pollution events such as dust storms, biomass combustion, and firework displays, which take place on many occasions in certain periods, could impact negatively to the air quality [38].

The need for this research was necessitated by the fact that Nigeria like most developing counties lack continuous air quality monitoring stations, hence unavailability of air quality data base. This is in addition to paucity of air quality reports on $\mathrm{PM}_{10}$ in the study area.

\section{MATERIALS AND METHODS}

Study Area. The study was carried out in Imo State (figure 1). Imo State is located in the tropical rainforest zone climate, within the coordinates $5.4833^{\circ} \mathrm{N}, 7.0333^{\circ} \mathrm{E}$. The area is dominated by plains with elevation ranging from $50-200 \mathrm{~m}$ above sea level. The annual rainfall is about $2400 \mathrm{~mm}$ to $4000 \mathrm{~mm}$, which is concentrated almost entirely between April and October, with average relative humidity of about $80 \%$ and up to $90 \%$ occurring during the wet season. The maximum air temperature ranges from 28 to $38^{\circ} \mathrm{C}$, while the minimum air temperature range from $19^{\circ} \mathrm{C}$ to $24^{0} \mathrm{C}$ [39-41]. 


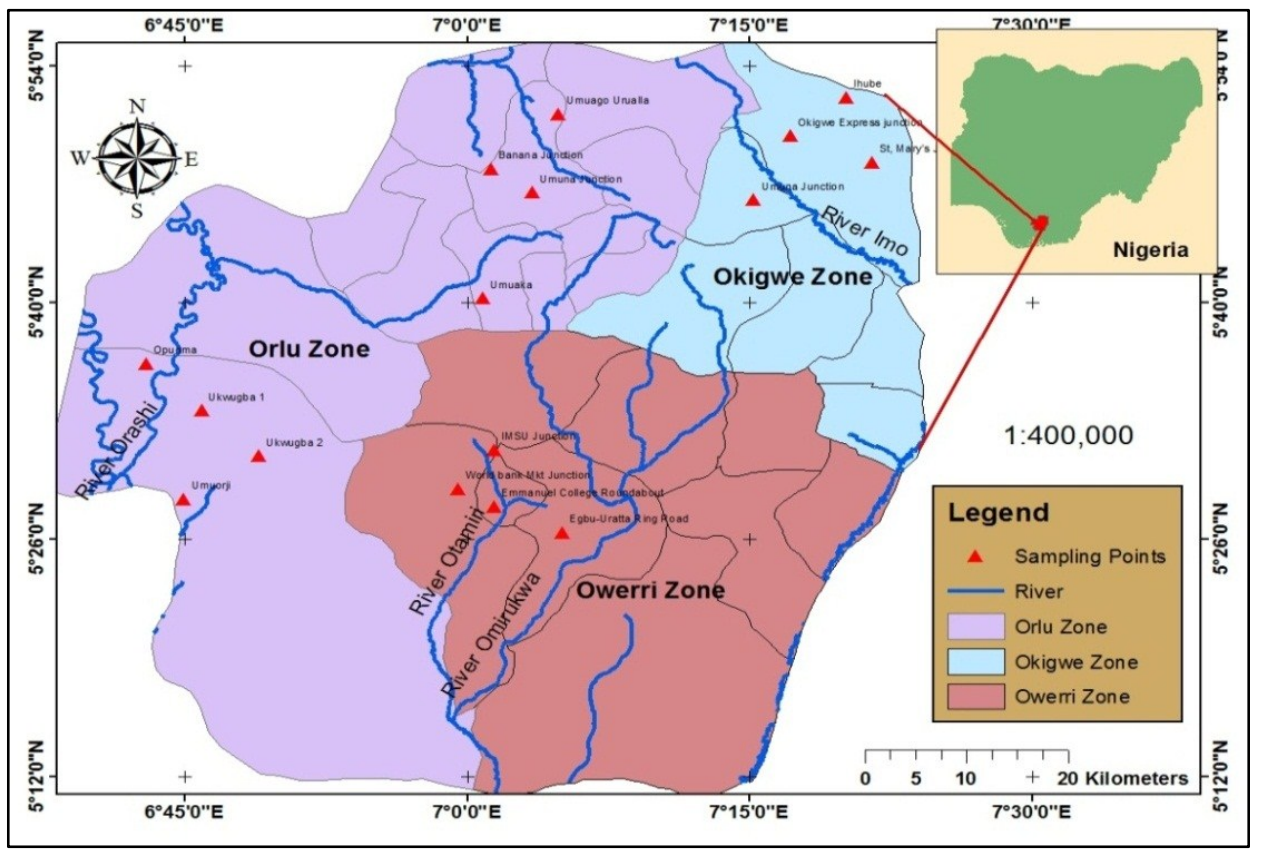

Fig. 1. Map of Imo State showing air pollution monitoring locations

Description of Study area. Imo State has a population of about 3,934,899 as at 2006[42]. This figure must have increased tremendously after almost ten years. The presence of stone mining sites in Okigwe and quarrying activities in neighboring towns could be a huge source of particulate matter emission into the ambient environment of the state, and this quarry products or stones are transported to different places by heavy duty trucks that uses diesel which could contribute significantly to air quality deterioration. Orlu city is fast growing with a lot of commercial activities, use of power generators, high volume of vehicular traffic and presence of two stroke engine automobiles like motorcycles and tricycle. Owerri, the capital of Imo State has high population density [42], with a lot of commercial activities, use of power generators, high volume of vehicular traffic and presence of two stroke engine automobiles like motorcycles and tricycles used for transportation, known for their incomplete combustion of fuel which could lead to the emission of noxious atmospheric air pollutants [29]. The State is located in the Niger Delta region of Nigeria blessed with natural resources like natural gas and crude oil mainly within Ohaji, Egbema and Oguta area of the State and most of the oil wells have enormous natural gas associated with them, which has a rough estimated future supply of about 1422 billion cubic meters [43]. Part of this gas has been continuously flared in this region since 1970 [44]. Also, Ohaji, Egbema and Oguta area have enormous farm lands hence most people here are farmers and the type of agricultural practices like bush burning generates much particulate matters. The study therefore was carried out in these areas described above which include Owerri, Orlu, Okigwe and Egbema with a total of four sampling station in each location. This amounts to sixteen (16) air quality sampling stations. Air quality monitoring sites were chosen in these locations for the analysis of particulate matter $\left(\mathrm{PM}_{10}\right)$ variation in the atmospheric environment of Imo State, Nigeria.

Air quality sampling Procedure. The air pollutant, $\mathrm{PM}_{10}$, was sampled three times a day (morning, afternoon and evening) [46], using Haze-Dust Particulate Monitor 10 $\mu \mathrm{m}$, model, HD1000, Environmental Device Corporation, USA. The air monitor was calibrated according to the manufacturer's directions before being deployed for the air quality sampling. Sampling was carried out for six month during dry and wet seasons, between November 2014 and June 2015. The air sampling was carried out once a week in each of the 16 air monitoring locations, three times per day, four times a month for a period of twenty four (24) weeks, which was within dry and wet seasons.

Data interpretation. Data analysis was done using Microsoft excel 2010, values of all the results from the 16 sampling points in the four locations which were recorded as calculated mean values of the air pollutant concentration in the morning, afternoon and evening hours, indicating minimum, 
maximum values and standard deviation (SD). The level of $\mathrm{PM}_{10}$ variation in (morning, afternoon, and evening) at different locations was determined using variance (VAR) and co-efficient of variation $(\mathrm{CV} \%)$. This was categorized as little variation $(\mathrm{CV} \%<20)$, moderate variation $(\mathrm{CV} \%=20-50)$ and high variation $(\mathrm{CV} \%>50)$ [47]. Contour and 3-D surface plots of the air pollutant concentration were modeled using Surfer 12 software, while the spatial distribution map of $\mathrm{PM}_{10}$ was modeled with Arc GIS 10.2. Matlab 7.9 version was used to carry out the ANOVA $(\mathrm{p}<0.05)$ and time series analysis. Box and Whisker plots were also plotted to further elucidate the variation of this air pollutant at each of the air sampling location in the morning, afternoon and evening, indicating the median, lower and upper quartiles [48].

\section{RESULTS AND DISCUSSION}

Geospatial Variation of $\mathbf{P M}_{10}$ in wet season. The summary of wet season result of $\mathrm{PM}_{10}$ variation in the atmospheric environment of Imo State is presented in table 1 for wet season. Fig. 2 is the contour and 3-D surface plot of $\mathrm{PM}_{10}$ variation in wet season, while fig. 3 is the spatial variation map of $\mathrm{PM}_{10}$ in wet season. The result of $\mathrm{PM}_{10}$ as presented in table 1 for wet season shows that at Owerri, the mean concentration of $\mathrm{PM}_{10}\left(\mathrm{mg} / \mathrm{m}^{3}\right)$ ranged from $5.22-6.63$. The mean value recorded in Okigwe is between $6.75-7.40 \mathrm{mg} / \mathrm{m}^{3}$, the value in Orlu ranged from $6.95-7.06 \mathrm{mg} / \mathrm{m}^{3}$, while in Egbema, the mean $\mathrm{PM}_{10}\left(\mathrm{mg} / \mathrm{m}^{3}\right)$ is between 6.89 - 7.00. In wet season the maximum value was $7.40 \mathrm{mg} / \mathrm{m}^{3}$ while the minimum value was $4.61 \mathrm{mg} / \mathrm{m}^{3}$ which were observed in Okigwe and Owerri respectively. The mean $\mathrm{PM}_{10}$ values obtained from semi- urban and rural areas of Orluand Egbema respectively are relatively lower when compared with Owerri and Okigwe. Fig. 2 shows the contour and 3-D surface plot of $\mathrm{PM}_{10}$ variation in the study area in wet season which indicates that elevated values were observed in Okigwe area of the study locations. This is also depicted in the spatial variation map of $\mathrm{PM}_{10}$ as presented in fig. 3. The order of variation in the morning is Egbema $>$ Okigwe $>$ Orlu $>$ Owerri, while afternoon is Egbema $>$ Owerri $>$ Orlu $>$ Okigwe and evening is in the order; Owerri $>$ Okigwe $>$ Orlu $>$ Egbema. This is also shown in table 1 from the result of coefficient of variation ( $\mathrm{CV} \%$ ), which indicates little variation for $\mathrm{PM}_{10}$ in all the locations. The result of $\mathrm{PM}_{10}$ obtained in wet season supports the idea of wide-spread, regional pollution of PM aerosols due to long-range transport of particulate and gaseous pollutants as noted by Gomiscek et al [49].

Table 1. Summary of wet season result of $\mathrm{PM}_{10}$ variation $\left[\mathrm{mg} / \mathrm{m}^{3}\right]$

\begin{tabular}{cccccccccccccc}
\hline & \multicolumn{3}{c}{ Owerri } & \multicolumn{4}{c}{ Okigwe } & \multicolumn{3}{c}{ Orlu } & \multicolumn{3}{c}{ Egbema } \\
\hline & M & A & E & M & A & E & M & A & E & M & A & E \\
Max & 5.69 & 6.91 & 7.32 & 7.40 & 6.75 & 7.02 & 7.06 & 6.95 & 7.01 & 6.98 & 7.00 & 6.89 \\
Min & 4.61 & 5.36 & 5.91 & 4.93 & 5.53 & 5.60 & 5.38 & 5.50 & 5.49 & 5.50 & 5.49 & 5.49 \\
Mean & 5.22 & 6.14 & 6.63 & 6.12 & 6.03 & 6.23 & 6.11 & 6.13 & 6.16 & 6.15 & 6.17 & 6.14 \\
Var & 0.12 & 0.21 & 0.21 & 0.75 & 0.13 & 0.16 & 0.25 & 0.17 & 0.19 & 0.17 & 0.18 & 0.17 \\
SD & 0.34 & 0.46 & 0.45 & 0.87 & 0.36 & 0.40 & 0.50 & 0.41 & 0.43 & 0.42 & 0.43 & 0.42 \\
CV \% & 6.51 & 7.49 & 6.79 & 14.22 & 5.97 & 6.42 & 8.18 & 6.69 & 6.98 & 6.83 & 6.97 & 6.84 \\
\hline
\end{tabular}

(Where $\mathrm{M}=$ morning, $\mathrm{A}=$ afternoon and $\mathrm{E}=$ evening, Max= maximum value, Min= minimum value Var= variance, $\mathrm{SD}=$ standard deviation and $\mathrm{CV} \%=$ co-efficient of variation) 

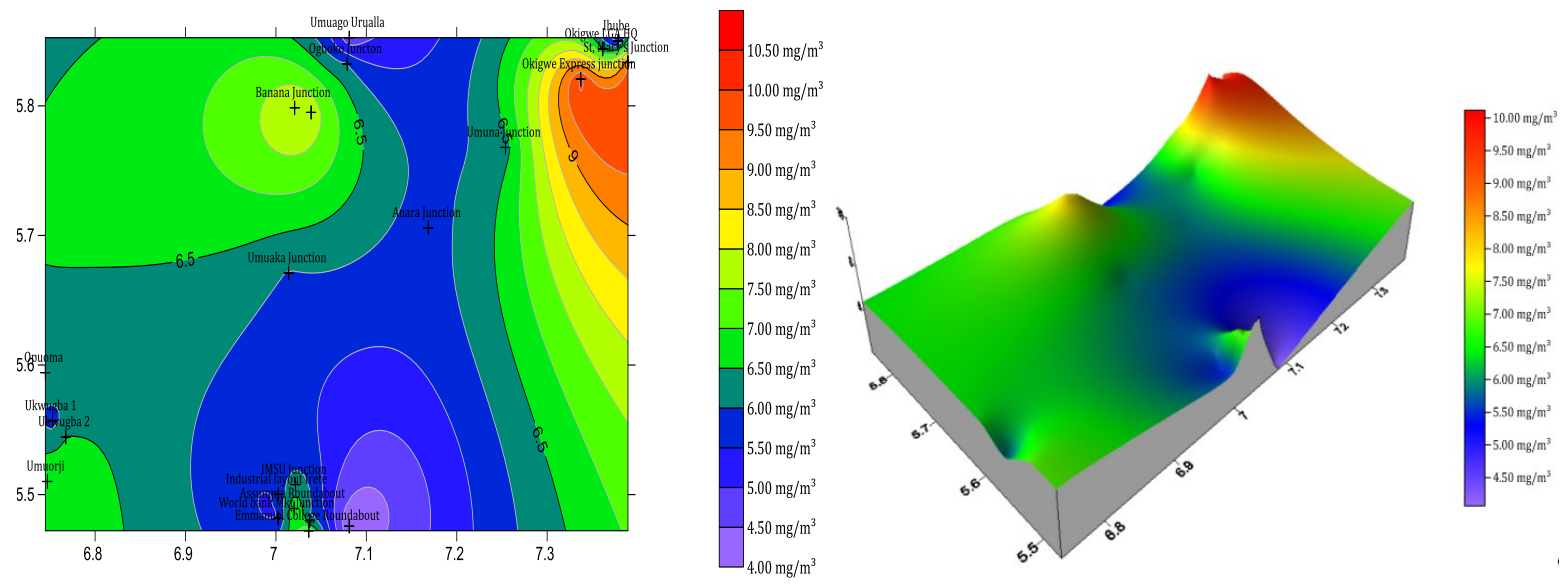

Fig. 2. Contour and 3-D surface plot of $\mathrm{PM}_{10}$ variation in the study area (wet season)

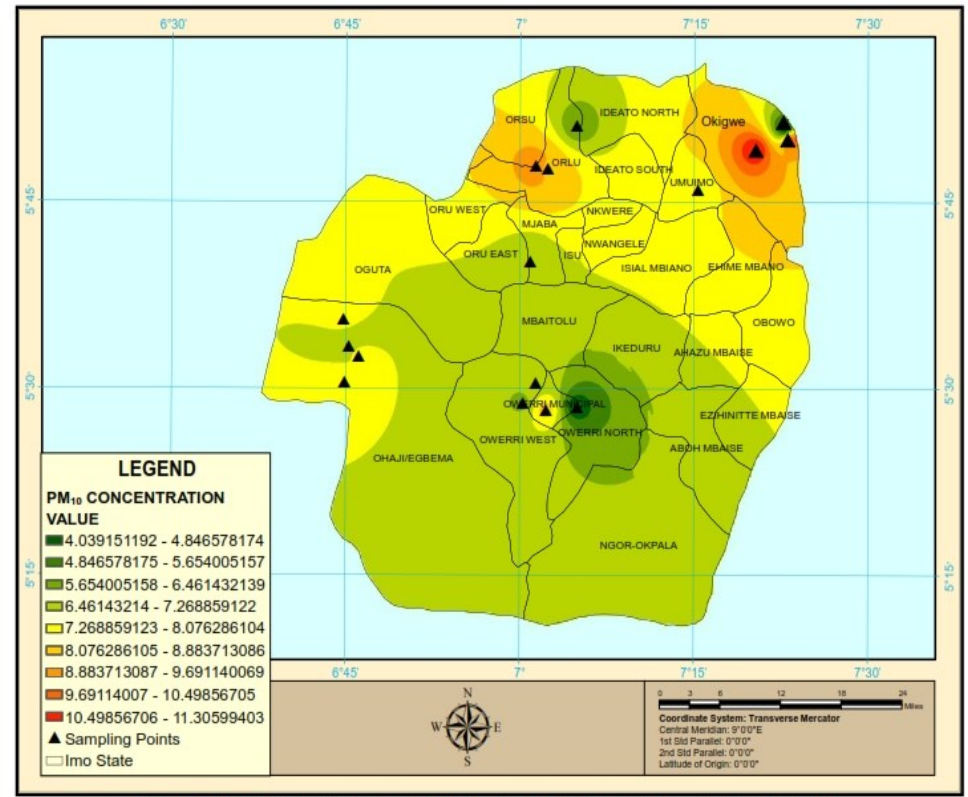

PM $_{10}$ SPATIAL DISTRIBUTION MAP OF STUDY AREA (WET SEASON)

Fig. 3. Spatial variation map of $\mathrm{PM}_{10}$ in wet season

Geostatistical analysis of $\mathbf{P M}_{10}$ in wet season. The variation of $\mathrm{PM}_{10}$ in the study locations are presented using Box and Whisker plots as shown in fig.4 - 7. The coefficient of variation (CV\%) as shown in table 1 indicates little to moderate variations. Analysis of variance (ANOVA at $\mathrm{p}>0.05$ ) was also carried out in order to further elucidate the variations in the study locations. Fig. 4 is the Box and Whisker plots of $\mathrm{PM}_{10}$ variation at Owerri in wet season. The plot indicates that in the morning, $25 \%$ of the data lie above $4.70 \mathrm{mg} / \mathrm{m}^{3}$ while $75 \%$ lies above $5.60 \mathrm{mg} / \mathrm{m}^{3}$. The afternoon air sampling revealed that $25 \%$ lie around $5.50 \mathrm{mg} / \mathrm{m}^{3}$ while $75 \%$ of the data are within $6.30 \mathrm{mg} / \mathrm{m}^{3}$. In the evening it was observed that $25 \%$ of the data were little below $6.00 \mathrm{mg} / \mathrm{m}^{3}$ while $75 \%$ of the data were within $6.80 \mathrm{mg} / \mathrm{m}^{3}$ of the results recorded. In addition ANOVA result $(\mathrm{F}=13.05$, sig. value $\left.=6.6702 e^{-5}, \mathrm{p}>0.05\right)$ shows that there is a significant difference in the mean level of $\mathrm{PM}_{10}$ observed in Owerri in wet season. 


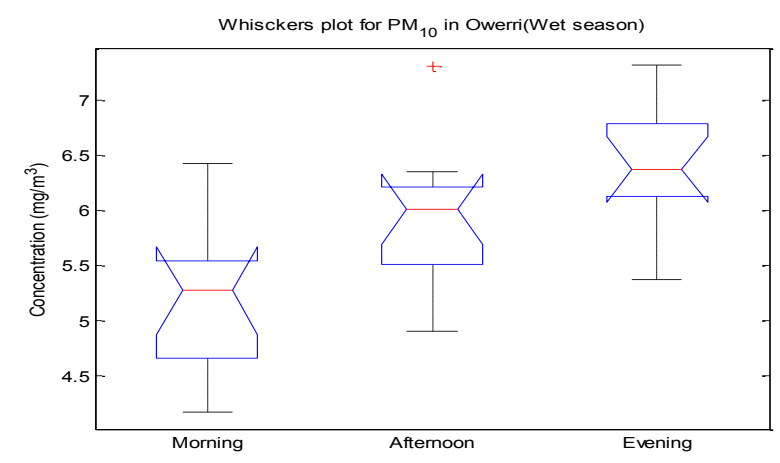

Fig. 4. Box and Whisker plot of $\mathrm{PM}_{10}$ variation at Owerri (wet season)

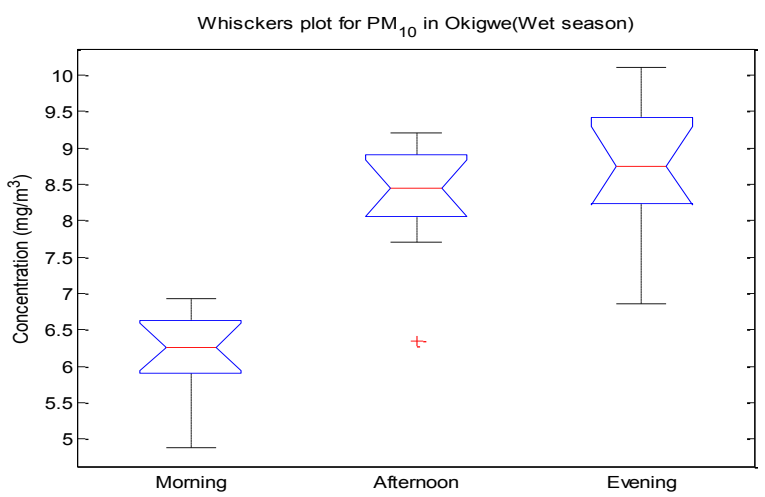

Fig. 5. Box and Whisker plot of $\mathrm{PM}_{10}$ variation at Okigwe (wet season)

Fig.5 is the Box and Whisker plots of $\mathrm{PM}_{10}$ variation at Okigwe in wet season. It shows that generally, higher mean values were recorded in the afternoon and evening hours. Fig.5 reveals that $25 \%$ of the results are within $5.90-8.30 \mathrm{mg} / \mathrm{m}^{3}$ for morning, afternoon and evening, while $75 \%$ of the results are within $6.70-9.40 \mathrm{mg} / \mathrm{m}^{3}$ for the same morning, afternoon and evening. ANOVA result $\left(\mathrm{F}=39.65\right.$, sig. value $\left.=1.677 e^{-9}, \mathrm{p}<0.05\right)$ indicates that there is a significant difference in the mean $\mathrm{PM}_{10}$ level observed at Okigwe in wet season.

In the case of Orlu in wet season, fig. 6 is the Box and Whisker plots of $\mathrm{PM}_{10}$ variation in wet season. It revealed that the lower and upper quartile respectively lies within $4.50 \mathrm{mg} / \mathrm{m}^{3}$ and $5.80 \mathrm{mg} / \mathrm{m}^{3}$ in the morning, while in the afternoon, $25 \%$ and $75 \%$ of the results obtained are within $6.30 \mathrm{mg} / \mathrm{m}^{3}$ and $7.40 \mathrm{mg} / \mathrm{m}^{3}$ respectively. It was observed that in the evening hours, $25 \%$ of the results recorded are within $7.20 \mathrm{mg} / \mathrm{m}^{3}$ while $75 \%$ are within $8.10 \mathrm{mg} / \mathrm{m}^{3}$. ANOVA result $(\mathrm{F}=28.78, \mathrm{p}<0.05)$ at a significant value of $5.8336 e^{-8}$ below 0.05 indicating that there is a statistical significant difference in the mean values of $\mathrm{PM}_{10}$ recorded at Orlu in wet season.

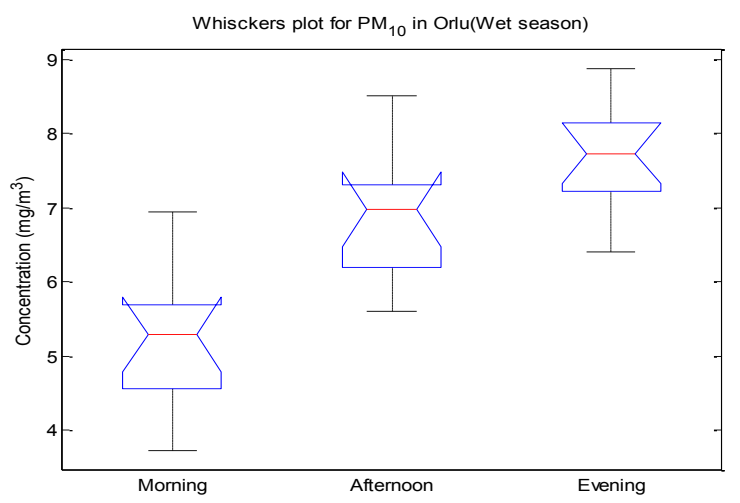

Fig. 6. Box and Whiskerplotof $\mathrm{PM}_{10}$ variation at Orlu (wet season) 


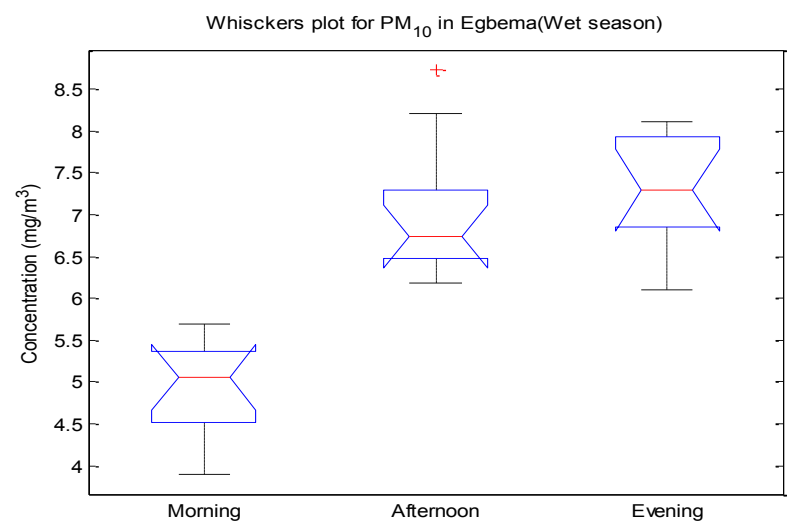

Fig. 7. Box and Whisker plot of $\mathrm{PM}_{10}$ variation at Egbema(wet season)

Fig. 7 is the Box and Whisker plots of $\mathrm{PM}_{10}$ variation at Egbema in wet season. Similarly, it was observed that in fig. 7, 25\% and $75 \%$ of the results are respectively within 4.50 and $5.40 \mathrm{mg} / \mathrm{m}^{3}$ in the morning, while in the afternoon $25 \%$ and $75 \%$ of the results are within $6.50 \mathrm{mg} / \mathrm{m}^{3}$ and $7.30 \mathrm{mg} / \mathrm{m}^{3}$ respectively. It was also observed that in the evening $25 \%$ and $75 \%$ of the results are respectively within $6.70 \mathrm{mg} / \mathrm{m}^{3}$ and $7.9 \mathrm{mg} / \mathrm{m}^{3}$. ANOVA result $\left(\mathrm{F}=46.76\right.$, sig. value $=2.3462 e^{-10}$, $\mathrm{p}>0.05$ ) shows that there is a statistically significant difference in the mean concentration of $\mathrm{PM}_{10}$ recorded at Egbema in wet season.

Variation of mean $\mathbf{P M}_{10}$ level across study locations in wet season. Variation of mean $\mathrm{PM}_{10}$ values across study locations in wet season is presented in fig. 8 which indicates variation of the air pollutant from week one to week twelve. The result indicates that elevated values of $\mathrm{PM}_{10} \mathrm{Were}$ recorded in week 4, 9, 10, 11 and12 at Okigwe. This location in Imo States is known for stone mining and quarry activities within and around the area, which could contribute significantly to the concentration of particulate matter in this area [50]. Also, it could be observed that elevated level of $\mathrm{PM}_{10}$ was recorded in Egbema. The location is a rural area though with the presence of gas flare starks [51], the observed elevated values of $\mathrm{PM}_{10}$ could also result from bush burning and other agricultural practices [15].

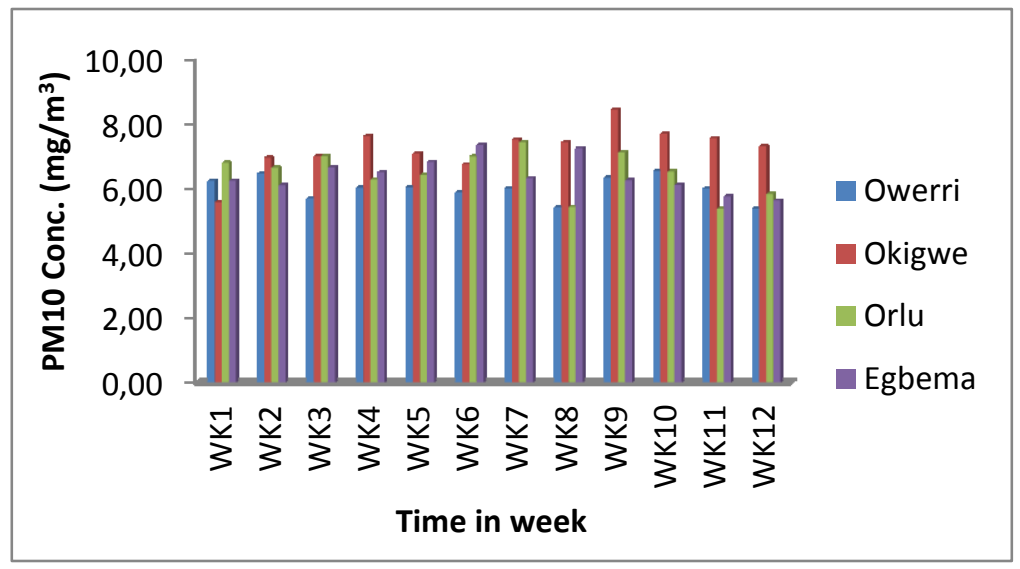

Fig. 8. Variation of mean $\mathrm{PM}_{10}$ values across study locations in wet season

Geospatial Variation of $\mathbf{P} \mathbf{M}_{10}$ in dry season. The summary of dry season variation of $\mathrm{PM}_{10}$ in the atmospheric environment of Imo State is presented in table 2. Fig.9 is the contour and 3-D surface plot of $\mathrm{PM}_{10}$ variation in dry season, while fig. 10 is spatial variation map of $\mathrm{PM}_{10}$ in dry season. Table 2 indicates that the mean concentration of $\mathrm{PM}_{10}\left(\mathrm{mg} / \mathrm{m}^{3}\right)$ recorded in Owerri in dry season ranged from $5.80-7.28$. While the mean $\mathrm{PM}_{10}\left(\mathrm{mg} / \mathrm{m}^{3}\right)$ observed in Okigwe ranged from $6.92-$ 7.87. Table 2 also indicates that the mean $\mathrm{PM}_{10}$ value recorded at Orlu in dry season ranged from $6.72-7.77\left(\mathrm{mg} / \mathrm{m}^{3}\right)$. The mean value of $\mathrm{PM}_{10}\left(\mathrm{mg} / \mathrm{m}^{3}\right)$ recorded in Egbema ranged from $7.42-$ 
8.38. The highest $\mathrm{PM}_{10}$ mean value of $8.38 \mathrm{mg} / \mathrm{m}^{3}$ was observed at Egbema in the afternoon while the lowest mean value of $5.80 \mathrm{mg} / \mathrm{m}^{3}$ was recorded at Owerri in the morning in dry season as shown in table 2. It has been earlier noted that Egbema is a rural area though with gas flare starks within and around the area [51]. Also as noted earlier agricultural activities in this area could have contributed significantly to the observed $\mathrm{PM}_{10}$ level. This is supported by the fact that agricultural activities is responsible for $\sim 18 \%$ of $\mathrm{PM}_{10}$ emissions arising from wind erosion, tillage operations, animal movement and others as reported by Rhonda [52], again other agricultural practices such as bush burning may have contributed to the $\mathrm{PM}_{10}$ level in this area [15]. Apart from Egbema, elevated value of $\mathrm{PM}_{10}$ was also observed in Okigwe area which could be due to quarry and stone mining activities in this area. This is agreement with Nartey et al who noted that dust emission is one of the major effects of quarrying activities [53]. Variation of $\mathrm{PM}_{10}$ in dry season is also illustrated with contour, 3-D surface plots and spatial distribution map as shown in fig.9 and 10. The order of mean $\mathrm{PM}_{10}$ variation in the morning is Egbema $>$ Okigwe $>$ Orlu $>$ Owerri. The order of $\mathrm{PM}_{10}$ variation in the afternoon is the same as in the morning, while in the evening, the mean $\mathrm{PM}_{10}$ level is Egbema> Orlu $>$ Okigwe $>$ Owerri. The result of coefficient of variation (CV \%) range from little to moderate variation as shown in table 2 . In both morning, afternoon and evening as earlier noted elevated levels of $\mathrm{PM}_{10}$ was observed in Egbema while lower values was recorded in Owerri. The result in table 2 indicates that elevated values of $\mathrm{PM}_{10}$ was observed in the afternoon and evening hours than in the morning. This observation agrees with earlier report in a related study [46].

Table 2. Summary of dry season result of $\mathrm{PM}_{10}$ variation $\left[\mathrm{mg} / \mathrm{m}^{3}\right]$

\begin{tabular}{ccccccccccccc}
\hline & \multicolumn{3}{c}{ Owerri } & \multicolumn{3}{c}{ Okigwe } & \multicolumn{3}{c}{ Orlu } & \multicolumn{3}{c}{ Egbema } \\
\hline & M & A & E & M & A & E & M & A & E & M & A & E \\
Max & 9.09 & 10.94 & 9.62 & 9.97 & 11.72 & 10.74 & 8.79 & 10.02 & 9.18 & 9.93 & 10.63 & 10.15 \\
Min & 4.79 & 5.53 & 5.73 & 3.13 & 4.73 & 4.73 & 4.92 & 6.02 & 6.43 & 6.00 & 6.38 & 6.08 \\
Mean & 5.80 & 7.25 & 7.28 & 6.92 & 7.87 & 7.52 & 6.72 & 7.77 & 7.53 & 7.42 & 8.38 & 7.88 \\
Var & 1.48 & 2.11 & 1.31 & 3.78 & 4.74 & 3.64 & 1.07 & 1.77 & 0.94 & 1.35 & 2.14 & 2.16 \\
SD & 1.22 & 1.45 & 1.15 & 1.94 & 2.18 & 1.91 & 1.03 & 1.33 & 0.97 & 1.16 & 1.46 & 1.47 \\
CV\% & 21.03 & 20.00 & 15.80 & 28.03 & 27.70 & 25.40 & 15.33 & 17.11 & 12.90 & 15.63 & 17.42 & 18.65 \\
\hline
\end{tabular}

(Where $\mathrm{M}=$ morning, $\mathrm{A}=$ afternoon and $\mathrm{E}=$ evening, $\mathrm{Max}=$ maximum value, $\mathrm{Min}=$ minimum value Var= variance, $\mathrm{SD}=$ standard deviation and $\mathrm{CV} \%=\%$ co-efficient of variation)
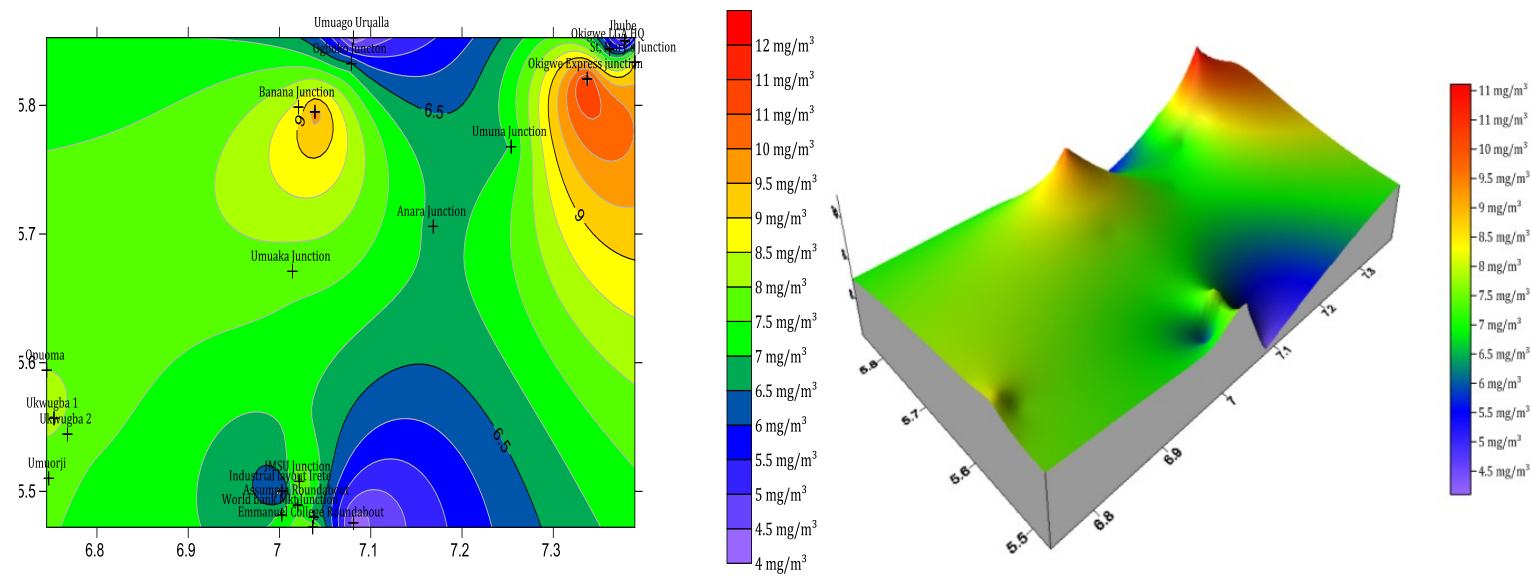

Fig. 9. Contour and 3-D surface plot of $\mathrm{PM}_{10}$ variation in dry season 


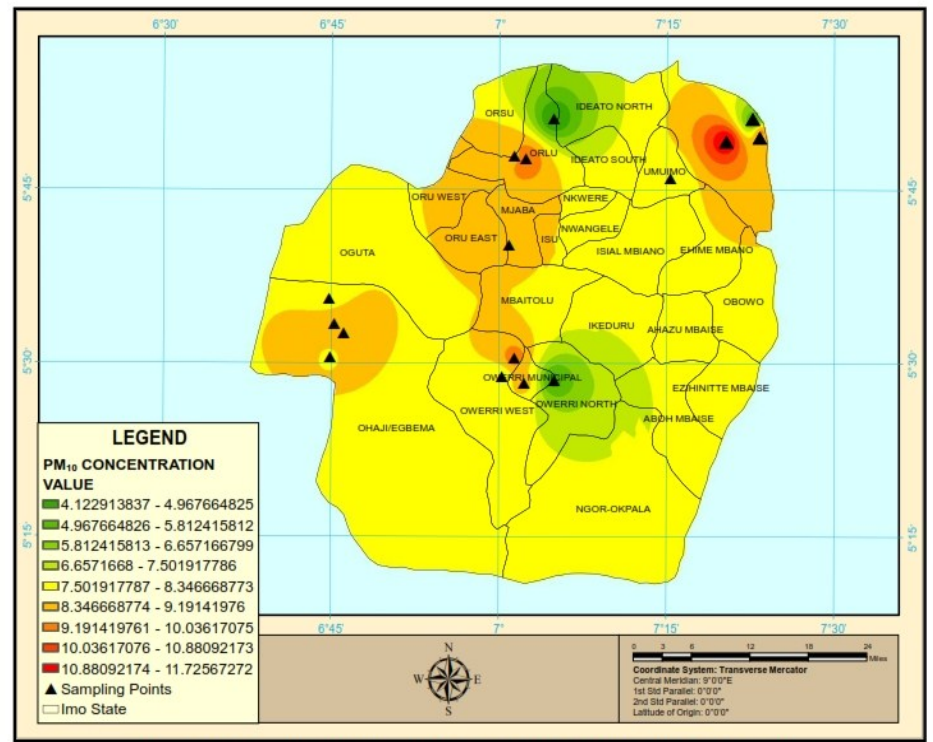

PM $_{10}$ SPATIAL DISTRIBUTION MAP OF STUDY AREA (DRY SEASON)

Fig. 10. Spatial variation map of $\mathrm{PM}_{10}$ in dry season

Geostatistical analysis of $\mathbf{P M}_{10}$ in dry season. Box and Whisker plots were employed to explain the dry season variation of $\mathrm{PM}_{10}$ in each of the air quality sampling location as shown in fig. 11 to 14. Fig. 11 is the Box and Whisker plot of $\mathrm{PM}_{10}$ variation at Owerri in dry season. Fig. 11 shows that $25 \%$ and $75 \%$ of $\mathrm{PM}_{10}$ values recorded at Owerri in the morning during dry season are within $5.00 \mathrm{mg} / \mathrm{m}^{3}$ and $5.90 \mathrm{mg} / \mathrm{m}^{3}$ respectively. In the afternoon, the Box and Whisker plot indicates that $25 \%$ and $75 \%$ of the results recorded lies respectively within $6.50 \mathrm{mg} / \mathrm{m}^{3}$ and $7.80 \mathrm{mg} / \mathrm{m}^{3}$. On the other hand, in the evening it was observed that $25 \%$ and $75 \%$ of the $\mathrm{PM}_{10}$ values obtained are within $6.70 \mathrm{mg} / \mathrm{m}^{3}$ and $8.20 \mathrm{mg} / \mathrm{m}^{3}$ respectively. Furthermore, ANOVA result $(F=7.03$, sig. value $=0.0029$ indicates that there is a statistically significant difference in the mean level of $\mathrm{PM}_{10}$ recorded at Owerri in dry season.

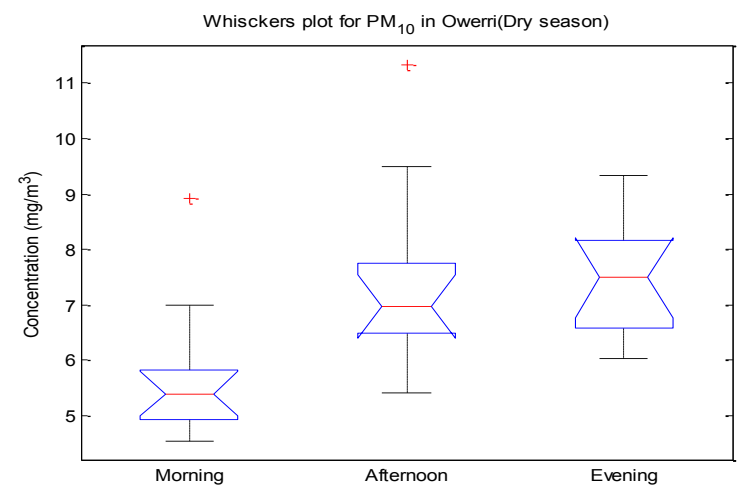

Fig. 11. Box and Whisker plotof $\mathrm{PM}_{10}$ variation at Owerri (dry season)

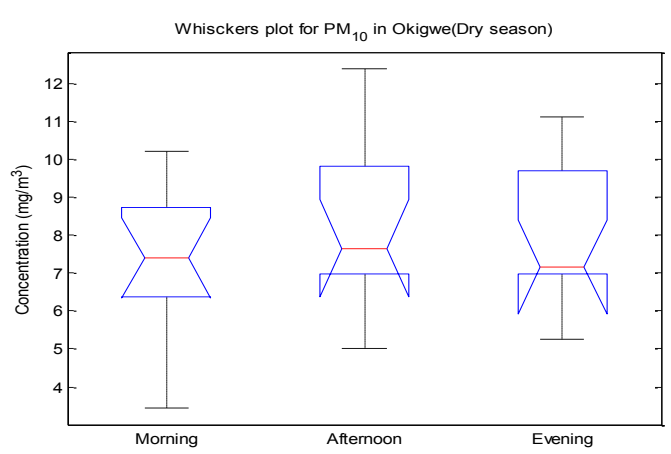

Fig. 12. Box and Whisker plot of $\mathrm{PM}_{10}$ variation at Okigwe (dry season) 


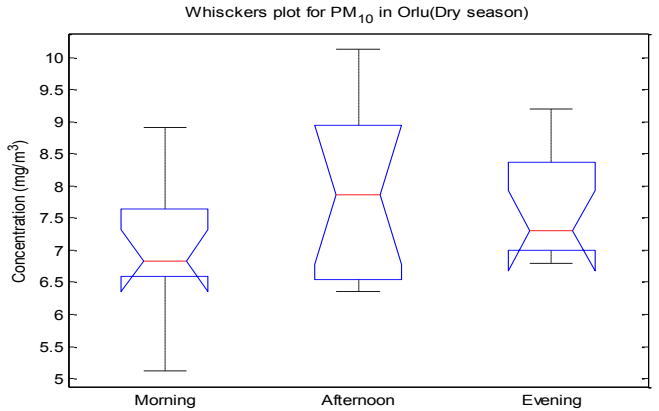

Fig. 13. Box and Whisker plot of $\mathrm{PM}_{10}$ variation at Orlu (dry season)

The dry season variation of $\mathrm{PM}_{10}$ at Okigwe is presented in table 2 and fig12. Table 2 indicates that the mean $\mathrm{PM}_{10}$ recorded in the morning, afternoon and evening do not differ significantly as the $\mathrm{CV} \%$ for morning, afternoon and evening are between $25.40-28.03 \%$, which is an indication of moderate variation. Fig. 12 is the Box and Whisker plot of $\mathrm{PM}_{10}$ variation at Okigwe in dry season. It indicates that $25 \%$ and $75 \%$ of the result recorded in the morning are respectively within 6.40 $\mathrm{mg} / \mathrm{m}^{3}$ and $8.80 \mathrm{mg} / \mathrm{m}^{3}$, while in the afternoon, $25 \%$ and $75 \%$ of the value recorded are within 6.90 $\mathrm{mg} / \mathrm{m}^{3}$ and $9.90 \mathrm{mg} / \mathrm{m}^{3}$ respectively. In a similar way, $25 \%$ and $75 \%$ of the results recorded in the evening at Okigwe in dry season are respectively within $7.00 \mathrm{mg} / \mathrm{m}^{3}$ and $8.20 \mathrm{mg} / \mathrm{m}^{3}$. Analysis of variance (ANOVA at $p>0.05, F=0.65$, sig. value $=0.5295$ ) shows no statistically significant difference in the mean value of $\mathrm{PM}_{10}$ observed at Okigwe in dry season.

Furthermore, the variation of mean $\mathrm{PM}_{10}$ values in Orlu is presented in table 2 and fig. 13 . Little variation was recorded in the morning, afternoon and evening hours as indicated by the CV\% values presented in table 2. Fig. 13 is the Box and Whisker plot of $\mathrm{PM}_{10}$ variation at Orlu in dry season. It shows that $25 \%$ and $75 \%$ of the results recorded in the morning are within $6.70 \mathrm{mg} / \mathrm{m}^{3}$ and $7.70 \mathrm{mg} / \mathrm{m}^{3}$ respectively. Similarly, in the afternoon, $25 \%$ and $75 \%$ of the values are within $6.60 \mathrm{mg} / \mathrm{m}^{3}$ and $8.90 \mathrm{mg} / \mathrm{m}^{3}$ respectively. It was observed that in the evening, $25 \%$ and $75 \%$ of the results are respectively within $7.00 \mathrm{mg} / \mathrm{m}^{3}$ and $8.40 \mathrm{mg} / \mathrm{m}^{3}$. The result of ANOVA $(\mathrm{F}=2.08$, sig. value $=0.1414, p>0.05$ ) shows that there is no statistically significant difference in the mean concentration of $\mathrm{PM}_{10}$ values observed at Orlu in dry season.

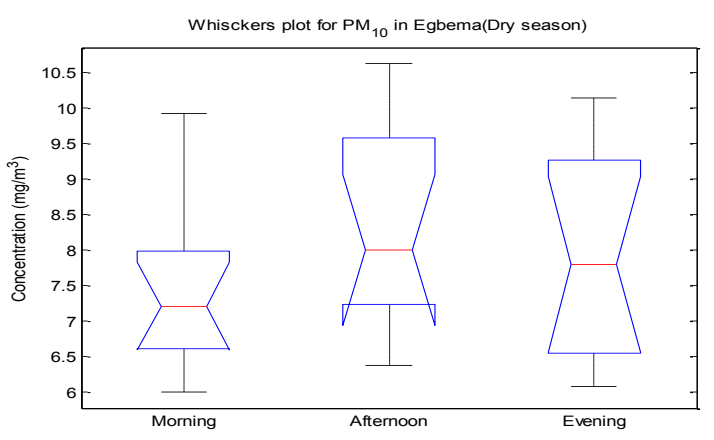

Fig. 14. Box and Whisker plotof $\mathrm{PM}_{10}$ variation at Egbema (dry season)

The $\mathrm{PM}_{10}$ variation in dry season at Egbema is presented in table 2 and fig. 14 . Table 2 shows that the mean $\mathrm{PM}_{10}$ level at Egbema is in the order morning $>$ afternoon $>$ evening. The values of $\mathrm{CV} \%$ indicate little variation within the air quality sampling locations. Fig. 14 is the Box and Whisker plot of $\mathrm{PM}_{10}$ variation at Egbema in dry season in dry season. The result indicates that in the morning, $25 \%$ and $75 \%$ of the $\mathrm{PM}_{10}$ values are respectively within $6.60 \mathrm{mg} / \mathrm{m}^{3}$ and 8.00 $\mathrm{mg} / \mathrm{m}^{3}$, while in the afternoon $25 \%$ and $75 \%$ of the result are within $7.30 \mathrm{mg} / \mathrm{m}^{3}$ and $9.70 \mathrm{mg} / \mathrm{m}^{3}$ respectively. In the evening, $25 \%$ and $75 \%$ of the $\mathrm{PM}_{10}$ values recorded in dry season are within $6.50 \mathrm{mg} / \mathrm{m}^{3}$ and $9.40 \mathrm{mg} / \mathrm{m}^{3}$ respectively. ANOVA result $\left(\mathrm{F}=13.05\right.$, sig. values $\left.=6.6701 e^{-5}\right)$ indicates that there is a significant difference in the mean level of $\mathrm{PM}_{10}$ concentration observed at Egbema in dry season. 
Variation of mean $\mathbf{P M}_{10}$ level across study locations in dry season.Fig.15 is the variation of mean $\mathrm{PM}_{10}$ values across study locations in dry season. This shows the variation of the air pollutant from week one to week twelve in dry season. The result indicates that elevated values $\mathrm{PM}_{10}$ were recorded in week 4,5 and 6 at Egbema. While in week 8 higher $\mathrm{PM}_{10}$ values were observed in all the locations as shown in fig.15. This supports the idea of wide-spread, regional pollution of PM aerosols due to long-range transport of particulate and gaseous pollutants earlier noted [49]. Also in week 9, 10 and 11 higher concentrations of $\mathrm{PM}_{10}$ were observed in Okigwe. This is not out of place, Okigwe area is known for stone mining and quarrying activities which could contribute significantly to $\mathrm{PM}_{10}$ as earlier remarked. Reports has it that mining activities could constitute fugitive dust sources which may influence air quality levels in the urban areas around the quarries [54]. Though the amount and composition of fugitive dust emanating from quarrying and mining activities is cumbersome to assess, the US emission factors for mineral handling, quarrying and mining range from 0.007 to $0.119 \mathrm{~kg} /$ ton of waste produced [55]. It has been reported that $\mathrm{PM}_{10}$ could increase the seriousness of asthma attacks, exacerbate bronchitis and other lung diseases, which could weaken the body's capability to fight infections [56,57].

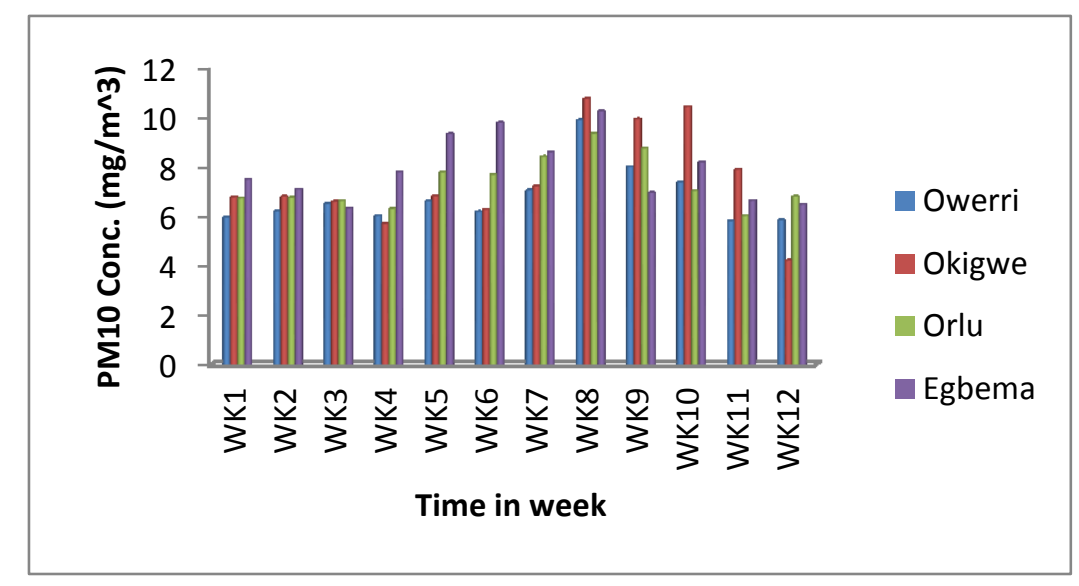

Fig. 15. Variation of mean $\mathrm{PM}_{10}$ values across study locations in dry season

Time series analysis of $\mathbf{P} \mathbf{M}_{10}$. The time series plots of $\mathrm{PM}_{10}$ are presented in Fig.16 - 19. In order to analyze and characterize the nature of temporal relationship during the air quality sampling, which was three times a day (morning, afternoon and evening) 4 times a month for a period of six months (3 months each for dry and wet season) which implies a total of 24 week. Time series models for each of the air pollutants at the 16 air sampling points were modeled based on weeks and time. Week 1 to 12 represents dry season while wet season is week 13 to 24 as shown in fig. $16-19$. Time series has been used in air pollution studies to evaluate changes in concentration of atmospheric pollutants [58 - 60]. The time series plots in fig. 16-19 indicate that the concentration of $\mathrm{PM}_{10}$ varied remarkably throughout the study period. In most cases elevated concentration of the pollutant was recorded in the afternoon and evening than in the morning hours. Fig 16a to 16d shows that higher concentration of $\mathrm{PM}_{10}$ was observed in dry season (week 1-12) than in wet season (week 13-24) in Owerri. Fig.17 reveals that the mean level of the pollutant measured in Orlu fluctuated tremendously showing no definite pattern except fig. 17d. Similarly, fig. 18 and 19 also showed significant variation in the concentration of $\mathrm{PM}_{10}$. The observed variation in concentration of $\mathrm{PM}_{10}$ as revealed by the time series could be due to changes with different locations and time resulting from changes in meteorological and topographical conditions of the location. 

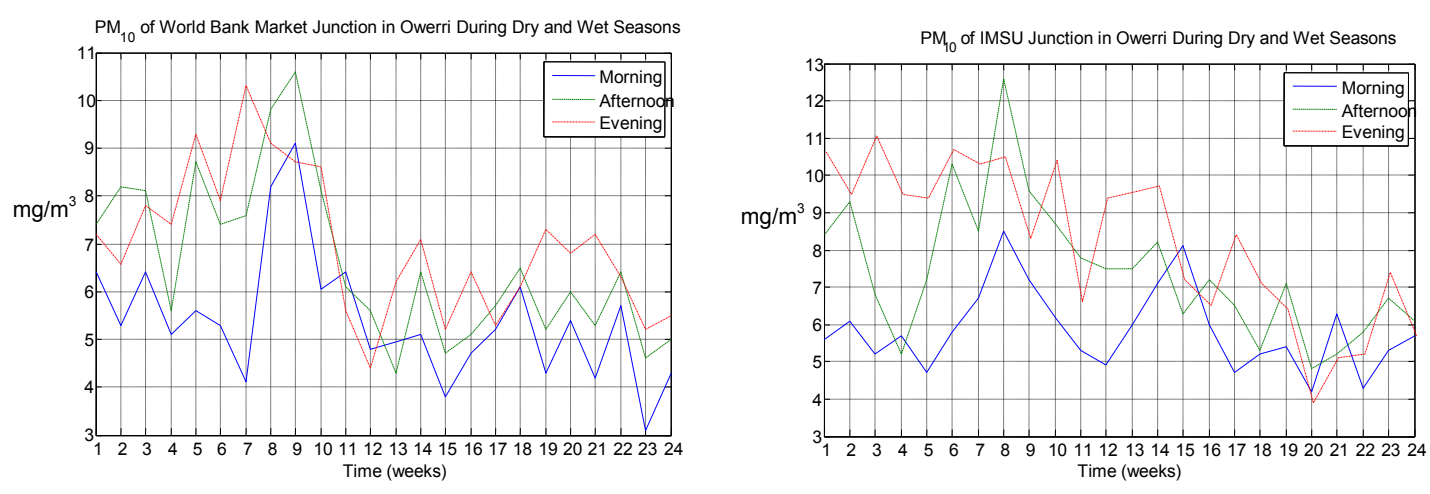

a
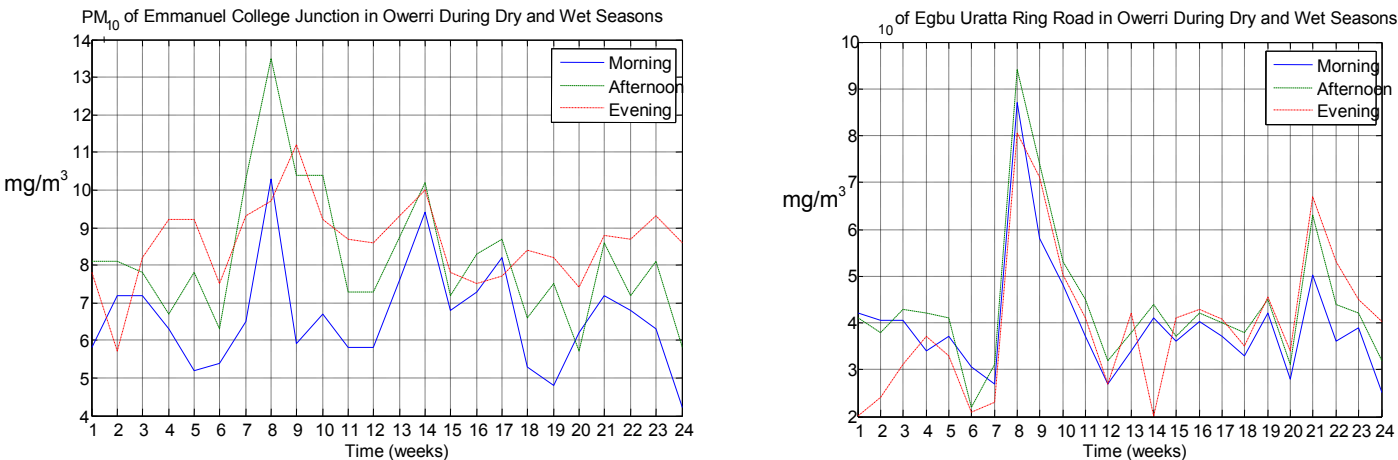

Fig. 16. Time series plots of $\mathrm{PM}_{10}$ at Owerri
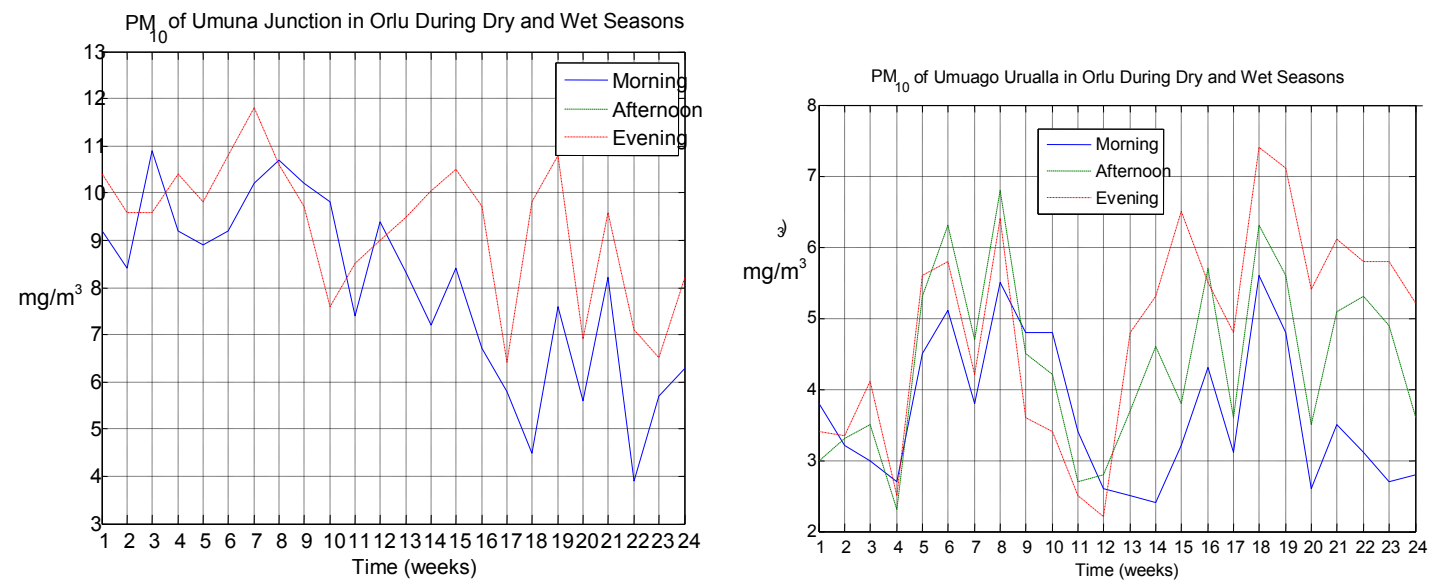

a
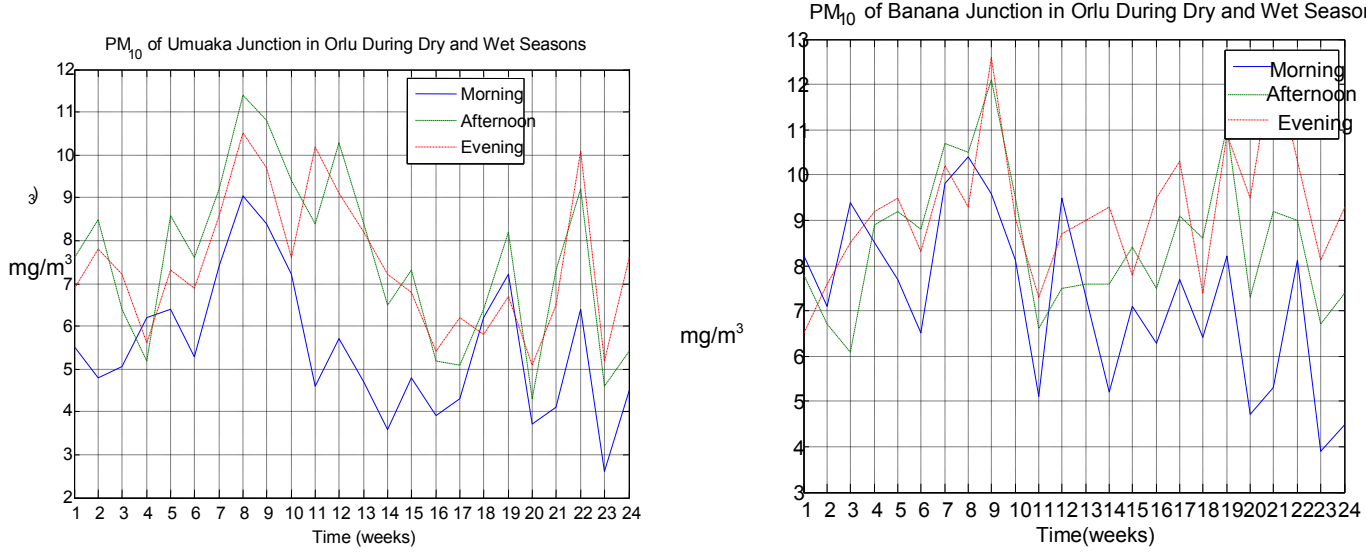

$\mathrm{c}$

Fig. 17. Time series plots of $\mathrm{PM}_{10}$ at Orlu 

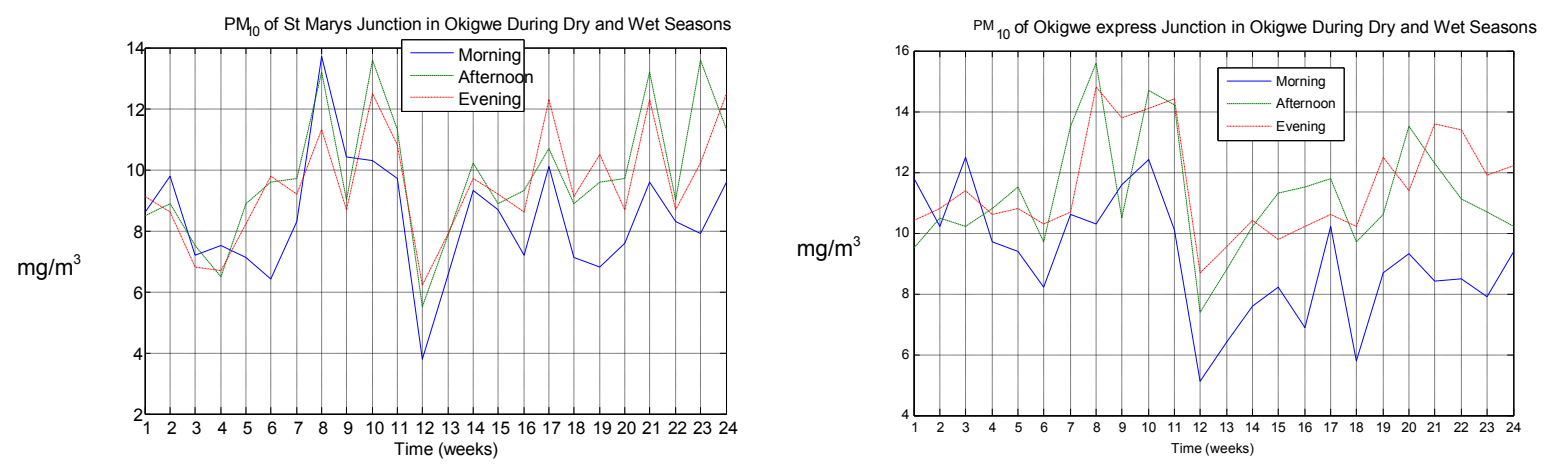

a
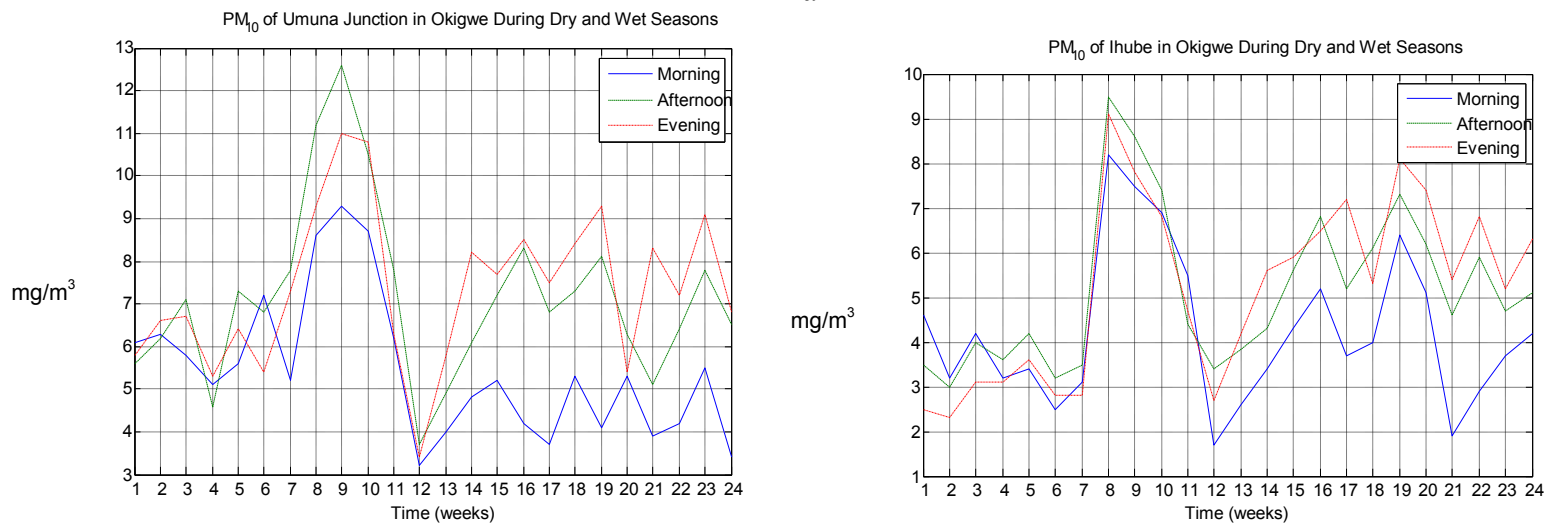

c

Fig. 18. Time series plots of $\mathrm{PM}_{10}$ at Okigwe
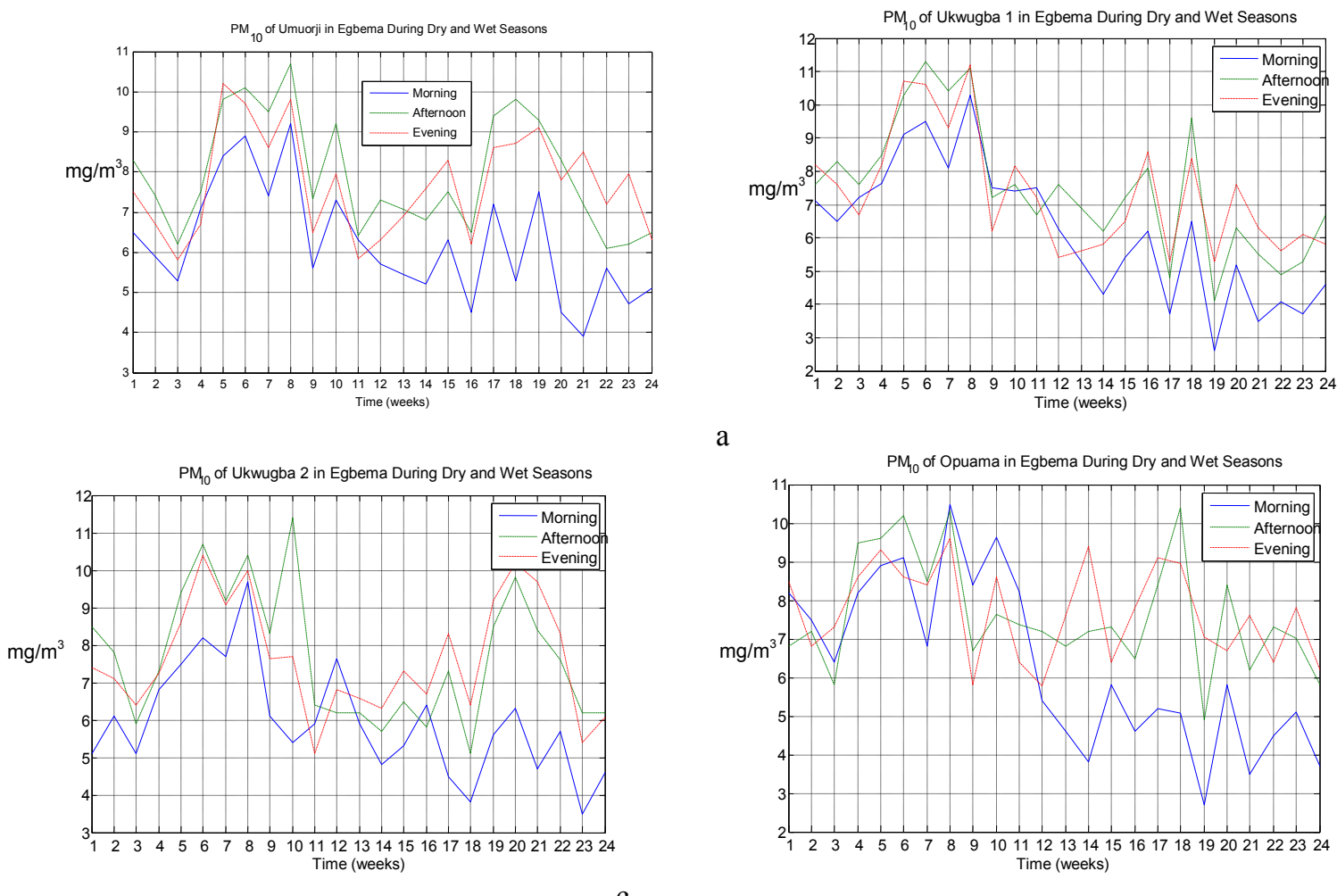

Fig. 19. Time series plots of $\mathrm{PM}_{10}$ at Egbema

Wind rose and dispersal of particulate pollution. The residence time of atmospheric pollutant such as particulate matter in the ambient environment and the formation of secondary pollutants are not only controlled by the concentration emitted from source of pollution but also by wind speed 
and wind direction. Wind speed and direction which make up the wind rose diagram provides realtime information on the migration and dispersal of air pollutant in an area in relationship to sources and pollutant levels [19]. Fig. 20 is samples of some wind rose diagrams obtained during the study which explains the dispersal of particulate matter $\left(\mathrm{PM}_{10}\right)$ emitted in the area. Fig. 20a, b, $c$ and $d$ are respectively the wind rose diagram for IMSU Junction, Owerri, Okigwe Express Junction, Okigwe, Banana Junction, Orlu and Umuorji in Egbema. The wind rose diagram is a summary of the wind speed and wind directions recorded in the morning, afternoon and evening during the $\mathrm{PM}_{10}$ airquality monitoring station in each location.

Results of the wind rose diagrams suggest that the dispersal and migration of $\mathrm{PM}_{10}$ is associated with the prevailing wind speed and wind directions observed in the study locations. The dominant wind speed in Owerri range from $0.9-3.5 \mathrm{~m} / \mathrm{s}$ in NE, SW and NW directions, while in Okigwe area the wind speed is between $<0.5-<3.5 \mathrm{~m} / \mathrm{sin} \mathrm{NE}, \mathrm{SW}$ and SE directions. In the case of Orlu area, the prevalent wind direction is NE, SW and NW with a wind speed ranging from $>0.5$ $>0.35$. It was observed that in Egbema area, the wind speed range from $>0.5->2$ in NW, SE and SW in directions. These predominant wind speeds and wind directions contribute significantly to the dispersal and migration of $\mathrm{PM}_{10}$ emitted in the study locations.
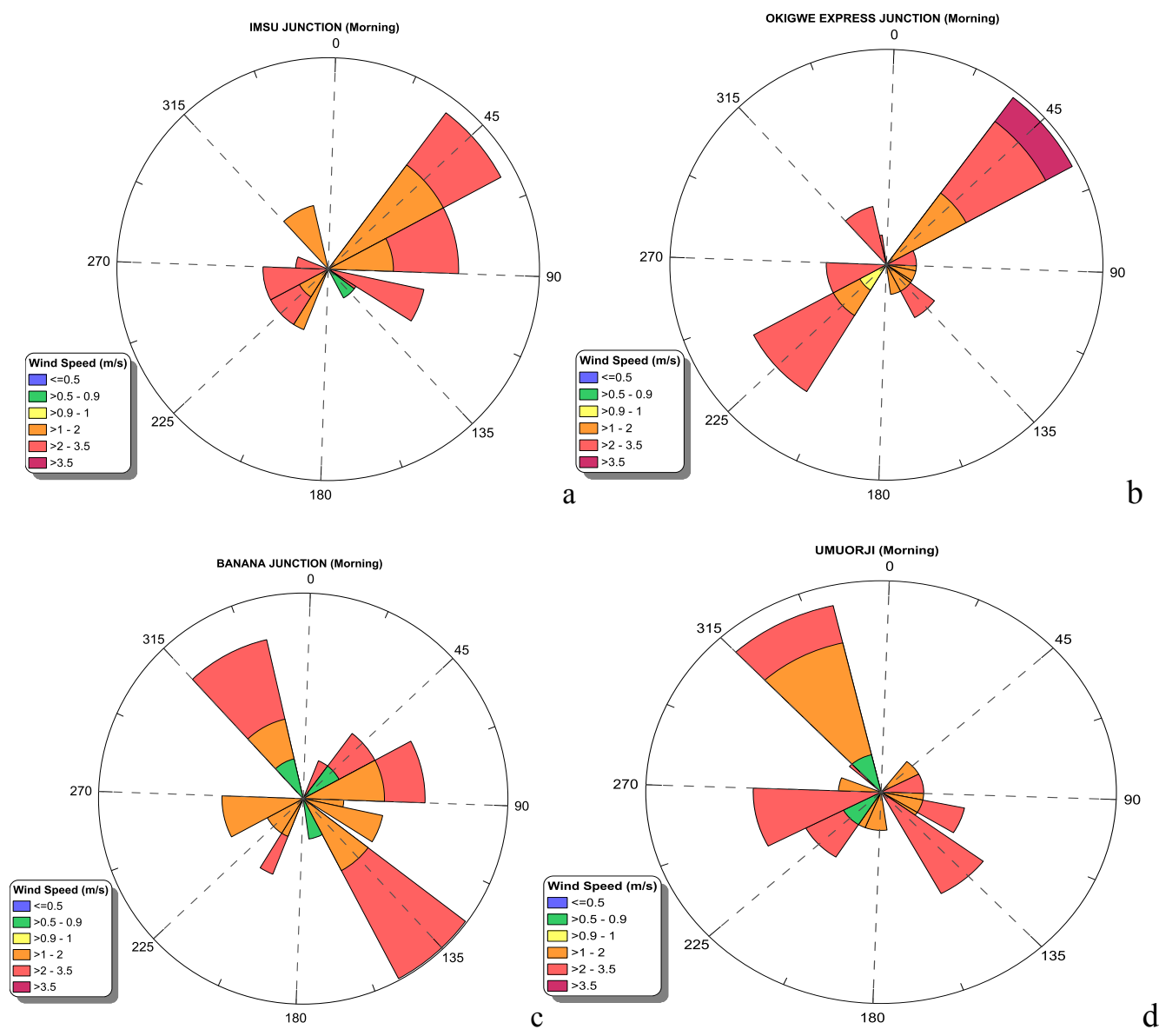

Fig. 20. Samples of some wind rose diagrams obtained during the study.

Comparison of mean $\mathbf{P M}_{10}$ level across study locations. Finally, fig.20 is the comparison of mean $\mathrm{PM}_{10}$ variation across study locations in dry and wet season. It indicates that generally higher $\mathrm{PM}_{10}$ values were observed in the dry season than in the wet season with Egbema showing the highest mean value as shown in fig. 21 . The highest dry seasonal mean $\left(7.90 \mathrm{mg} / \mathrm{m}^{3}\right)$ obtain in this study is above that reported in related studies in Nigeria [11,61]. In addition to earlier stated reasons, elevated $\mathrm{PM}_{10}$ levels in this area could be attributed to the episodic dust events of Sahara desert and its associated trans-boundary transportation $[62,63]$. 


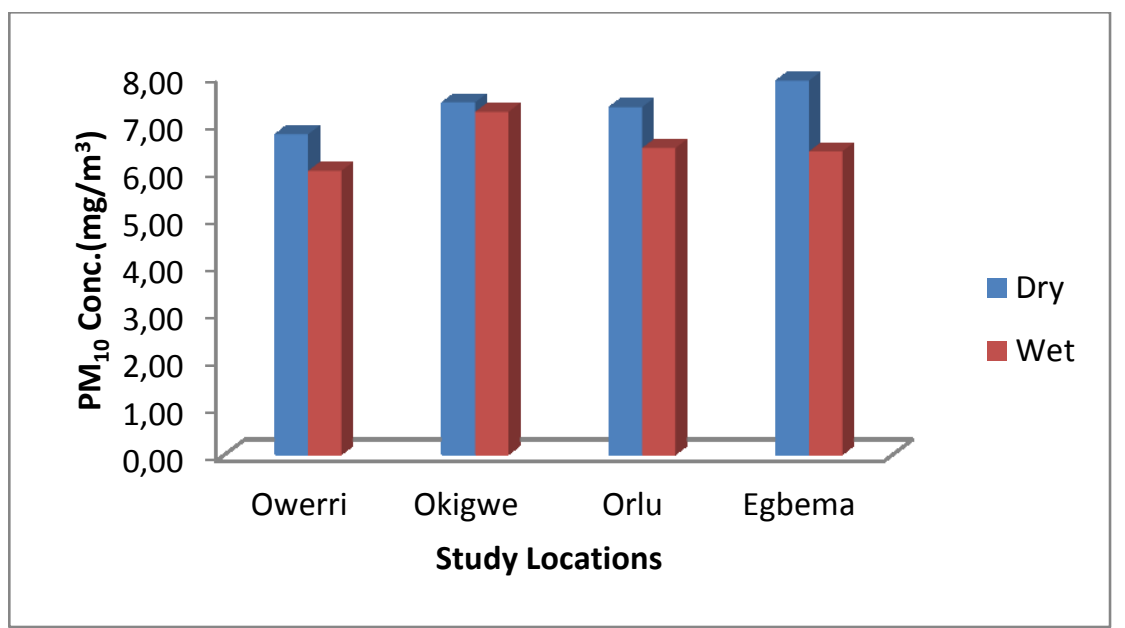

Fig. 21. Comparison of mean $\mathrm{PM}_{10}$ level across study locations (dry and wet season)

This is due to the fact that particles have different capacity to be transported over either short or long distances which depends on the particle size [64]. The mean $\mathrm{PM}_{10}$ levels in both wet and dry season exceeded the annual guide line values $\left(120 \mu \mathrm{g} / \mathrm{m}^{3}\right)\left(0.12 \mathrm{mg} / \mathrm{m}^{3}\right)$ of Nigerian National Ambient Air Quality Standards [65].

\section{Conclusion}

The study determined the variation of particulate matter in the atmospheric environment of Imo State, Nigeria. Concentrations of $\mathrm{PM}_{10}$ measured were observed to be affected by either wet or dry season, with the lowest and highest mean values obtained during wet and dry seasons respectively. Results of the study indicates that the variability of the measured $\mathrm{PM}_{10}$ concentration in the study locations ranged between little and moderate variation. The highest seasonal mean values were observed at Egbema and Okigwe area of the State in both dry and wet season. The Box and Whisker plots revealed that higher concentration of $\mathrm{PM}_{10}$ was observed in the afternoon and evening than in the morning in the study location. The study also indicates that the concentration of $\mathrm{PM}_{10}$ obtained in the study varied in different time of day when measurements were conducted. ANOVA, $\mathrm{p}<0.005$ result indicates that variation within most sampling locations (morning, afternoon and evening) showed statistically significant difference. Time series analysis confirmed that the mean concentration of the atmospheric pollutant fluctuated throughout the study duration. The mean $\mathrm{PM}_{10}$ values obtained within the time of this study exceeded the stipulated guideline values. This therefore implies that the people in this area will have to contend with exposure to particulate matter $\left(\mathrm{PM}_{10}\right)$ at levels above what is considered safe, even though the degree of exposure is yet to be understood.

\section{Acknowledgement}

The authors acknowledge the support from Laboratory Services and Environmental Research Department/UNIDO RAC for Pollution Monitoring and Assessment, Ministry of Environment and Petroleum, Imo State, Nigeria for providing the air quality monitoring equipment and assistant during the field work. 


\section{REFERENCE}

[1] P. Ravikumar, K.L. Prakash, R.K. Somashekar, Air quality indices to understand the ambient air quality in vicinity of dam sites of different irrigation projects in Karnataka State, India International Journal of Science and Nature. 5 (3) (2014) 531-541.

[2] K. Ravindra, A. K. Mittal, R. Van Grieken, Health risk assessment of urban suspended particulate matter with special reference to polycyclic aromatic hydrocarbons: A review. Rev. Environ. Health. 16 (2001) 169-189.

[3] M. Prakash, J.K. Bassin, Analysis of ambient air quality using air quality index - a case study, International Journal of Advanced Engineering Technology, Vol. 1 (II) (2010) 106-114.

[4] J. M. Okuo, P.O Okolo, Levels of $\mathrm{As}, \mathrm{Pb}, \mathrm{Cd}$ and $\mathrm{Fe}$ in total suspended particulate matter (TSPM) in ambient air of artisan's workshops in Benin City, Nigeria, J.Sci and Ind. Stud. 1(1) (2003) $32-35$.

[5] I. U. Chiemeka, Air aerosols metal constituents and concentration at Okigwe Nigeria, Int.J. of Physical Sc. 5(4) (2010) $283-286$.

[6] G. Majewski, M. Klenieewska, A. Brandyk, Seasonal variation of particulate matter mass concentration and content of metal, Polish J. of Eniron. Stud. 20(2) (2011) 417 - 427.

[7] Understanding particle pollution, www3.epa.gov/airtrends/aqtrnd04/pmreport03/ pmunderstand_2405.pdf, accessed 10/01/2016.

[8] S. C. Bhatia, Environmental Chemistry, CBS Publishers, New Delhi-110002, India (2002) pp. $132-174$.

[9] S.E Manahan, Fundamentals of environmental chemistry, CRC press LLC, Boca Raton, (2011) pp. $521-529$.

[10] M. Langner, T. Draheim, W. Endlicher, Particulate Matter in the Urban Atmosphere: Concentration, Distribution, Reduction - Results of Studies in the Berlin Metropolitan Area; In Perspectives in Urban Ecology, W. Endlicher et al. (Eds.), Springer-Verlag Berlin Heidelberg, (2011) http://www.springer.com/978-3-642-17730-9, accessed10/01/2016.

[11] S.O. Ngele, F.K. Onwu, Measurement of ambient air fine and coarse particulate matter in ten South - East Nigerian cities. Res. J.Chem. Sc. 5(1) (2015) $71-77$.

[12] A.Pederzoli, M. Mircea, S. Finard, A. di Sarray, Zanini G., Quantification of Saharan 622 dust contribution to $\mathrm{PM}_{10}$ concentrations over Italy during 2003-2005, Atmos. Environ. 44 (2010) 41814190.

[13] D.R. Gomez, S.L. Reich, L.E. Dawidowski, C. Vazquez, A combined analysis to identifyairborne $\mathrm{PM}_{10}$ sources, J. Environ. Monit. 7(2005)52-59.

[14] V. P. Aneja, A. Aaron Isherwood, P. Morgan, Characterization of particulate matter $\left(\mathrm{PM}_{10}\right)$ related to surface coal mining operations in Appalachia, Atmospheric Environment 54 (2012) 496 501.

[15] S. Arslan, A. Aybeka, H. C. Ekerbdçer, Measurement of personal $\mathrm{PM}_{10}, \mathrm{PM}_{2.5}$ and $\mathrm{PM}_{1}$ exposures in tractor and combine operations and evaluation of health disturbances of operators, Journal of Agricultural Sciences. 16 (2010) 104-115.

[16] C.Y. Yang,C. C. Chang, H.Y. Chuang, S.S. Tsai, T. N. Wu, C.K. Ho, Relationship between air pollution and daily mortality in a subtropical city: Taipei Taiwan, Environ Int. 30 (2004) 519-23.

[17] R. Afroz, M. N. Hassan, N. A. Ibrahim Review of air pollution and health impacts in Malaysia, Environmental Research. 93(2) (2003) 71-78.

[18] S. M. Hassan and M. E. Abdullahi, Evaluation of pollutants in ambient air; A case study of Abuja, Nigeria, Int. J. Sci. and Research 2(12) (2012) 1-9.

[19] D. Giri, V. Krishna Murthy, P. R. Adhikary, The Influence of Meteorological Conditions on $\mathrm{PM}_{10}$ Concentrations in Kathmandu Valley, Int. J. Environ. Res. 2(1) (2008) 49-60

[20] P. K. Bhuyan, P. Samantray, S. P. Rout, Ambient air quality status in Choudwar area of Cuttack District. International J.Environmental Sciences. 3(1) (2010) 343-356.

[21] G. Norris, S.N. Youngpong, J.O. Koening, T.V. Larson, L. Sheppard, J.W. Stout, An association between fine particles and asthma emergency department visits for children in Seattle, Environ. Health Perspect. 107 (1999)489-493. 
[22] A.C. Pope, Epidemiology of Fine Particulate Air Pollution and Human Health, Biologic Mechanism and who's at Risk?, Environ. Health Perspect. 108 (2000) 713-723.

[23] J.M. Samet, F. Dominic, F.C. Currieo, T. Course, S. Zeagr, Fine Particulate Air Pollution and Mortality in29 US Cities 1987-1994, N. Engl. J. Med. 343 (2000) 1742-1749,

[24] S.G. Ong, J. Liu, C.M. Wong, T.H. Lam, A.Y. Tam, L Daniel, A.J. Hedley, Studies on respiratory health of primary school children in urban communities of Hong Kong, Science Total Environ. 106 (1991) 121-135.

[25] S.K Prajapati, B.D. Tripathi, Seasonal variation of leaf dust accumulation and pigment content in plant species exposed to urban particulate pollution, J. Environmental Quality. 37 (2008) 865870.

[26] EPA, Protecting visibility: An EPA report to congress,research triangle park, NC office of air quality and planning standards EPA report no. EPA-450/5-79-008 (1979).

[27] Y.J. Kim, K.W. Lee, S. Kim and J.S. Ham, Fineparticulate characteristics and its impact on visibility impairment at two urban sites in Korea; Seoul and Incheon, Atmospheric Environment. 40 (2006) 5593-5605.

[28] M. Ferm, J. Watt, S. O'Hanlon, F.De Santis, C.Varotasas, Deposition Measurement of particulate matter in connection with corrosion studies. Anal Chem. Bioanal. 384 (2006) 13201330.

[29] B. Sengupta (Ed.), Guidelines for ambient air quality monitoring, National ambient air quality monitoring series, NAAQMS. Central pollution control board, Parivesh Bhawan, East Ajun Nagar, Delhi, April, 2003, http://www.cpcb.nic.in/newitems/7.pdf accessed 20/03/2014.

[30] C.O. Ogba, B.P. Utang, Air pollution climatology in spatial planning for Sustainable development in the Niger Delta, Nigeria, TS 1D - Environment and land use planning, FIG working week 2009 Surveyor's Key Role in Accelerated Development, 3-8 May, 2009, Eilat, Israel. https://www.fig.net/resources/proceedings/fig_proceedings/fig2009/papers/ts01d/

ts01d_ogba_utang_3202.pdf accessed 19/12/15 (2009).

[31] F.C. Ibe, P.C. Njoku, J.I. Alinnor, A.I. Opara, Spatial variation of $\mathrm{NO}_{2}$ and $\mathrm{SO}_{2}$ in the ambient environment of Imo State, Nigeria, IJSET. 5(1) (2016) 33 - 46.

[32] D. Kim, K. Lee, J. Cha, S.Lee, Temporal and spatial distribution of troposphericNO $\mathrm{N}_{2}$ over Northeast Asia using OMI data during the years 2005-2010Atmospheric Pollution Research. 6 (2015) 768-777.

[33] T.W. Wong, W.W.S. Tam, A.K.H. Lau, S.K.W. Ng, I.T.S. Yu, A.H.S. Wong, D. Yeung, A Study of the Air Pollution Index Reporting System; Tender Ref. AP 07-085, Environmental Protection Department (EPD) of the Hong Kong, Final report, Hong Kong, 27 June 2012, pp. 1 - 51. www.epd. gov.hk/epd/epd/environmentinhk/air/studyrpts/APIreview, accessed 20/03/14.

[34] US, EPA, Air quality index (AQI); A guide to air quality and your health, U.S. Environmental Protection Agency, Office of Air Quality Planning and Standards, Outreach and Information Division. Research Triangle Park, NC. February 2014. EPA-456/F-14-002, www3.epa.gov/airnow/aqi_brochure_02_14.pdf,accessed 12/01/2016.

[35] C.S. Li, C.H. Lin, Carbon profile of residential indoor PM1 and PM2.5 in the subtropical region. Atmospheric Environment. 37 (2003) 881-888.

[36] O. Hanninen, G. Hoek, S. Mallone, E. Chellini, K. Katsouyanni, C. Gariazzo, G. Cattani, A. Marconi, P. Molnar, T. Bellander, M. Jantunen, Seasonal patterns of outdoor PM infiltration into indoor environments: Review and meta-analysis of available studies from different climatological zones in Europe. Air Quality Atmosphere and Health. 4 (2011) 221-233.

[37] S. Sidra, Z. Ali, Z., A. Nasir and I. Colbeck, Seasonal variation of fine particulate matter in residential micro-environments of Lahore, Pakistan, Atmospheric Pollution Research. 6 (2015) 797-804.

[38] W. Huang, E. Long, J. Wang, R. Huang and L. Ma, Characterizing spatial distribution and temporal variation of $\mathrm{PM}_{10}$ and $\mathrm{PM}_{2.5}$ mass concentrations in an urban area of Southwest China, Atmospheric Pollution Research. 6 (2015) 842-848. 
[39] E.A. Ubuoh, S. M.O. Akhionbare, Effect of pig production on the ambient air quality of Egbeada in Mbaitoli LGA of Imo State, Nigeria, J. Sci. and Multidisciplinary Research. 3 (2011) 816.

[40] U.K. Okoro, W. Chen, T.C. Chineke, O.K. Nwofor, Recent monsoon rainfall characteristics over the Niger Delta Region of Nigeria: A casual link, IJSET. 3 (2) (2014) 634-651.

[41] U.K. Okoro, W. Chen, T.C. Chineke, O.K. Nwofor Comparative analysis of gridded datasets and gauge measurements of rainfall in the Niger Delta region of Nigeria, Research Journal of Environ. Sci. 8(7) (2014) 373 - 390.

[42] FRN (Federal Republic of Nigeria), Official Gazette, Legal Notice on publication of the details of the Breakdown of the National and State Provisional total, 2006 Census. Federal Republic of Nigeria Official Gazette, Government Notice No. 21, Lagos, $15^{\text {th }}$ May, 2007, Vol. 94, pp 1-26.

[43] F. C. Ibe, P. C. Njoku, J. I. Alinnor, A. I. Opara, Evaluation of ambient air quality in parts of Imo State, Nigeria. Res. J. Chem. Sci. 6(1) (2016) 41-52.

[44] O. Odeyemi, and O.A. Ogunseitan, Petroleum Industry and its Pollution Potentialin Nigeria. Oil \& Petroleum Pollution, Applied Science. 2 (1985)223-228

[45] NNPC,(Nigeria National Petroleum Corporation), Nigerian National Petroleum Cooperation, Monthly Petroleum Information, September 1984, Lagos, Nigeria, Vol. 53.

[46] Y. Mohammed, J.J. Caleb, Assessment of some air pollutants and their corresponding air quality at selected activity areas in Kaduna metropolis. Proceedings of $37^{\text {th }}$ Annual International Conference of Chemical of Nigeria (SCN) at Uyo, Akwa Ibom State Nigeria, $7^{\text {th }}-12^{\text {th }}$ September, 2014,Vol. I (2014) 38 - 44.

[47] E.N. Verla, A.W. Verla, L. Ugwulor, Seasonal variation of heavy metals in playgrounds of public schools within Owerri Metropolis, Imo State, Nigeria, International Letters of Chemistry, Physics and Astronomy. 50 (2015) 61-70.

[48] D.S. Wilks, Statistical methods in the atmospheric sciences, $2^{\text {nd }}$ edition, Academic press, California, 2006.

[49] B. Gomisceka, H. Hauck, S. Stoppera, O. Preining, Spatial and temporal variations of $\mathrm{PM}_{1}$, $\mathrm{PM}_{2.5}, \mathrm{PM}_{10}$ and particle number concentration during the AUPHEP - project, Atmospheric Environment. 38 (2004) 3917 -3934.

[50] B.S. Bada, K.A. Olatunde, O.A. Oluwafunmilayo, Air quality assessment in the vicinity of quarry site, Environment and Natural Resources Research. 3(2) (2013) 111-115.

[51] N. Egwurugwu, A. Nwafor, O.J. Oluronfemi, S.C. Iwuji, E.A. Alagwu, Impact of prolonged exposure to oil and gas flares on human renal functions, Int. Res. J. Medical Sci. 1(11) (2013) 9-16.

[52] M. Rhonda, Air Quality and Agriculture, AG/Environment/2015-01pr, March 2015 https://agwastemanagement.usu.edu/Air_Quality_and_Agriculture.pdf. accessed 26/02/2016.

[53] V. K. Nartey, J. N. Nanor, R. K. Klake, Effects of quarry activities on some selected communities in the Lower Manya Krobo District of the Eastern Region of Ghana, Atmospheric and Climate Sciences. 2 (2012) 362-372.

[54] A. Titi, M. Dweirj, K. Tarawneh, Environmental effects of the Open Cast mining a Case Study: Irbid Area, North Jordan, American Journal of Industrial and Business Management. 5 (2015) 404423.

[55] United States Environmental Protection Agency, AP-42 Emission Factors. Brick and Structural Clay Product Manufacturing. U. S. Environmental Protection Agency Office of Air Quality Planning and Standards, Emission Factor and Inventory Group Research Triangle Park, NC 27711, August, 1997. https://www3.epa.gov/ttnchie1/ap42/ch11/bgdocs/b11s03.pdf, accessed 26/02/2016.

[56] M. Kampa, E. Castanas, Human Health Effects of Air Pollution. Environmental Pollution, 151 (2008) 362-367.

[57] Particulate Matter Pollution Fact Sheet, https://ndep.nv.gov/baqp/monitoring/ docs/particulate_matter.pdf, accessed 02/03/2016.

[58] R.A. Norrimi, A. R. Nor, I.M. Nuru, S. Y. Ahmad, Time Series Evaluation of Ozone Concentrations in Malaysia Based on Location of Monitoring Stations, International Journal of Engineering and Technology. 3(3) (2013) 390 - 394. 
[59] G. Nunnari, S. Dorling, U. Schlink, G. Cawley, R. Foxall, T. Chatterton, Modelling $\mathrm{SO}_{2}$ concentration at a point with statistical approaches, Environmental Modelling and Software. 19 (2004) 887-905.

[60] G.Saffarini, S. Odat, Time series analysis of air pollution in Al-Hashimeya Town Zarqa, Jordan, Jordan Journal of Earth and Environmental Sciences. 1(2) (2008) 63- 72.

[61] S.O. Ngele, N.I. Elom, P.A. Nwofe, P.E. Agbo, A.O. Ogah, R.C. Ehiri, Diurnal Variation of ambient air pollutants concentration in two motor parks in Ebonyi State, Nigeria, Adv. Environ. Biol. 9(23) (2015) 271-278.

[62] M. Marconi, D.M. Sferlazzo, S. Becagli, C. Bommarito, G. Calzolai, M. Chiari, A. di Sarra, C. Ghedini, J.L. Gómez-Amo, F Lucarelli., D. Meloni, F. Monteleone, S. Nava, G. Pace, S. Piacentino, F. Rugi, M. Severi, R. Traversi, R. Udisti, Saharan dust aerosol over the Central Mediterranean Sea: $\mathrm{PM}_{10}$ chemical composition and concentration versus optical columnar measurements, Atmos. Chem. Phys. 14 (2014) 2039 - 2054.

[63] F. Roda, J. Bellot, A. Avila, A. Escarra, J. Piiiol, J. Terradas, Saharan dust and the atmospheric inputs of elements and alkalinity to Mediterranean ecosystems. Water, Air and Soil Poll. 66 (1993) 277-288.

[64] J.M. Prospero, R.A. Glaccum, R.T. Nees, Atmospheric transport of soil dust from Africa to South America, Nature. 289 (1981) 570-572.

[65] FRN (Federal Republic of Nigeria) (2011), Official Gazette National Environmental (NonMetallic Minerals Manufacturing Industries Sector) Regulation, 2011, Federal Republic of Nigeria Official Gazette Government Notice No. 134, Lagos, $23^{\text {rd }}$ May, 2011, Vol. 98, pp B637 - B692. 